\title{
KONFLIK POLITIK ANTARA GUBERNUR DAN DPRD DKI JAKARTA DALAM PROSES PENETAPAN APBD 2015
}

\author{
Zainul $^{1}$, Yusuf Wibisono ${ }^{1}$ \\ ${ }^{1}$ Program Studi Ilmu Politik, Universitas Nasional \\ email : zainulunas@yahoo.co.id,yusufwibi03@yahoo.com
}

Korespondensi : yusufwibi03@yahoo.com

\begin{abstract}
In the implementation of regional autonomy and decentralization systems, the discourse on the pattern of power relations between the Regional Head and the Regional Representative Council (DPRD) is an interesting study. This is because in practice, the ups and downs of the relationship between the Regional Head and the Regional Parliament are influenced by the political dynamics that develop in the region, as was the case in the conflict between the Governor and the Regional Parliament of DKI Jakarta. Determination of the 2015 APBD. not only attracted a lot of public attention, but more importantly this case was a bad precedent for the administration of regional government. Starting from this, this study aims to analyze the factors that cause conflicts between the Governor and the DKI Jakarta DPRD in the 2015 APBD Determination, and to understand the patterns used in resolving political conflicts between the Governor of the DKI Jakarta DPRD in the 2015 APBD Determination. In order to answer the research problem, the theory used uses the theory put forward by Paul M. Collier who states that in general political conflict is caused by two things, namely because of differences in interests, and the seizure of scarce or very limited resources. While the theory of political conflict resolution used by Simon Fisher's theory, which states the pattern of conflict resolution is divided into three ways, namely negotiation, mediation, and arbitration. In accordance with the objectives to be achieved, this study was designed using qualitative research methods, with a case study approach. From the research findings, it is stated that the main factors causing conflict between the Governor and the DKI Jakarta $D P R D$ in determining the 2015 APBD are the divided local government factor, and the difference in political interests between the Governor and the DKI Jakarta DPRD. The conflict between the Governor and the DKI Jakarta DPRD finally found a common ground after a long process of resolution. The pattern of conflict resolution used is a mediation approach, by involving the Indonesian Ministry of Internal Affairs in resolving the conflict, to find a meeting point that is mutually beneficial to both parties.
\end{abstract}

Keywords: political conflict, relationship between regional head, dprd, apbd, dki jakarta

\begin{abstract}
Abstrak
Dalam penyelenggaraan sistem otonomi daerah dan desentralisasi, diskursus tentang pola relasi kekuasaan antara Kepala Daerah dan Dewan Perwakilan Rakyat Daerah (DPRD) menjadi kajian menarik. Hal ini mengingat dalam prakteknya, pasang surut hubungan Kepala Daerah dan DPRD dipengaruhi oleh dinamika politik yang berkembang di daerah, seperti halnya yang terjadi dalam konflik Gubernur dan DPRD
\end{abstract}


DKI Jakarta Penetapan APBD Tahun 2015. Konflik antara Gubernur DKI Basuki Tjahaya Purnama dan DPRD menarik untuk diteliti tidak hanya banyak menyita perhatian publik, namun yang lebih penting kasus ini merupakan preseden buruk bagi penyelenggaraan pemerintahan daerah. Beranjak dari hal tersebut penelitian ini bertujuan untuk menganalisa faktor-faktor penyebab terjadinya konflik antara Gubernur dan DPRD DKI Jakarta Dalam Penetapan APBD Tahun 2015, serta untuk memahami pola yang digunakan dalam penyelesaian konflik politik antara Gubernur DPRD DKI Jakarta Dalam Penetapan APBD Tahun 2015. Dalam rangka menjawab permasalahan penelitian, teori yang digunakan menggunakan teori yang dikemukakan Paul M. Collier yang menyebutkan bahwa secara garis besar konflik politik disebabkan oleh dua hal, yakni karena perbedaan kepentingan, dan perebutan sumber daya (resources) yang langka atau sangat terbatas. Sedangkan teori penyelesaian konflik politik yang digunakan teori yang dikemukakan Simon Fisher, yang menyebutkan pola penyelesaian konflik terbagi menjadi tiga cara, yakni negosiasi, mediasi, dan arbitrase. Sesuai dengan tujuan yang ingin dicapai, maka penelitian ini didesain dengan menggunakan metode penelitian kualitatif, dengan pendekatan studi kasus (case study). Dari hasil temuan penelitian menyebutkan bahwa faktor utama penyebab konflik antara Gubernur dan DPRD DKI Jakarta dalam penetapan APBD tahun 2015 adalah faktor pemerintahan daerah yang terbelah (divided local government), dan faktor perbedaan kepentingan politik antara Gubernur dan DPRD DKI Jakarta. Konflik antara Gubernur dan DPRD DKI Jakarta akhirnya menemukan titik temu setelah melalui proses panjang dalam upaya penyelesaiannya. Pola penyelesaian konflik yang digunakan adalah pendekatan mediasi, dengan mengikutsertakan Kementeriaan Dalam Negeri RI dalam penyelesaian konflik tersebut, untuk menemukan titik temu yang saling menguntungkan kedua belah pihak.

Kata kunci: konflik politik, hubungan kepala daerah, dprd, apbd, dki jakarta

\section{PENDAHULUAN \\ Latar Belakang Penelitian}

Relasi kekuasaan antara lembaga eksekutif dan legislatif di tingkat lokal merupakan salah satu isu menarik untuk dikaji seiring dengan perubahan politik lokal dengan pelaksanaan sistem otonomi daerah dan desentralisasi, dalam rangka mewujudkan proses demokratisasi di daerah. Penerapan otonomi daerah dan desentralisasi yang nyata bertanggungjawab menghendaki adanya penguatan kedaulatan rakyat pada tingkat lokal dengan memberikan konstribusi politik yang lebih besar, yang antara lain berhubungan dengan posisi rakyat dalam proses pemilihan pemimpin publik di daerah. Di mana masyarakat memiliki kebebasan untuk berpendapat dan memilih wakil-wakilnya yang duduk sebagai wakil-wakil mereka di lembaga legislatif maupun pemimpin publik di lembaga eksekutif pada tingkat lokal dengan bebas dalam sistem demokratis.

Disisi yang lain, kehadiran reformasi telah menghasilkan perubahan mengenai kedudukan dan peranan lembaga-lembaga penyelenggara pemerintahan, baik itu eksekutif, legislatif maupun yudikatif. Perubahan yang terjadi di tingkat pusat juga berdampak pada kedudukan dan peranan lembaga eksekutif dan legislatif di daerah. Berbagai peranan lembaga di daerah mengalami pergeseran dari mekanisme yang telah berlangsung selama ini. 
Dalam konteks ini, Ichlasul Amal (2000) berpendapat bahwa pola hubungan eksekutif-legislatif terbagi dalam tiga pola hubungan yakni "dominasi eksekutif, dominasi legislatif, dan hubungan yang seimbang", dan lebih lanjut dikatakannya dalam suatu sistem politik di negara ketiga pola hubungan tersebut tidak berjalan dengan tetap". Oleh karena itu untuk membangun pola hubungan yang ideal antara Legislatif dan Eksekutif dalam arti terciptanya keseimbangan antara kedua lembaga tersebut sangat tergantung pada sistem politik yang dibangun. Semakin demokratis sistem politik itu maka hubungan antara legislatif dan eksekutif akan semakin seimbang. Sebaliknya semakin tidak demokratis sistem politik suatu negara maka yang tercipta dua kemungkinan yaitu dominatif eksekutif yang mencipatakan rezim otoriter dan dominatif legislatif yang mencipatakan anarki politik.

Dalam pola yang seimbang antara legislatif dan eksekutif itu pulalah hubungan yang hendak dibangun antara legislatif dan eksekutif daerah dalam melaksanakan demokrasi lokal. Di mana melalui keseimbang kekuasaan antara legislatif dan eksekutif di daerah diharapakan mekanisme check and balances di tingkat lokal dapat direalisasikan dalam rangka memperjuangkan kepentingan rakyat sebagai pemilik kedaulatan tertinggi. Sebaliknya jika salah satu lebih dominan tentu akan menimbulkan gesekan-gesekan antara kepala daerah dan Dewan Perwakilan Rakyat Daerah (DPRD). Gesekan dapat berupa tarik menarik proses penetapan APBD, adanya penolakan DPRD terhadap pertanggung jawaban kepala daerah tanpa ada jawaban yang jelas, penolakan DPRD terhadap kebijakan kepala daerah, atau pemanggilan pejabat eksekutif tanpa pemberitahuan kepada kepala daerah, hal tersebut yang seringkali menjadi sebab perselisihan antara eksekutif dan legislatif dalam praktek penyelenggaraan pemerintahan di daerah.

Dari banyak literatur, terjadinya perselisihan antara eksekutif dan legislatif akan berdampak pada tataran pelayanan publik yang merugikan kepentingan masyarakat, mengingat bahwa perselisihan di kalangan elit politik akan berimbas pada konflik horisontal di kalangan masyarakat yang pada akhirnya akan mengganggu keamanan dan ketentraman yang berpengaruh pada pelaksanaan pembangunan dan peningkatan ekonomi masyarakat. Padahal semangat utama lahirnya Undang-Undang No. 32 Tahun 2004 tentang Pemerintahan Daerah, ingin menghadirkan kelembagaan politik lokal yang stabil, dengan menempatkan Kepala Daerah dan DPRD berkedudukan sejajar, sebagai mitra, dan kedua menjadi unsur penyelenggara pemerintahan daerah. Dalam UU No. 32 Tahun 2004 Pasal 19 secara eksplisit menjelaskan bahwa penyelenggara pemerintahan daerah adalah pemerintah daerah dan DPRD. Pasal ini, secara jelas memosisikan kedudukan DPRD sebagai penyelenggara pemerintahan di daerah. Implikasi pasal ini, aktivitas penyelenggaraan pemerintahan harus dilakukan bersama-sama antara DPRD dan kepala daerah. Aktivitas penyelenggaraan ini meliputi tugas-tugas desentralisasi dan tugas pembantuan.

Ketentuan pasal ini menekankan baik kepala daerah maupun DPRD dalam aktivitas penyelenggaraan pemerintahan menekankan pada service sphere 
bukan pada political sphere. Pemahaman politik dalam perspektif UU No. 32 Tahun 2004 tidak menjangkau pada penjatuhan kepala daerah karena dalam UU ini tidak dikenal dengan sistem parlementer. Dalam UU Nomor 32 Tahun 2004 sama sekali tidak dikenal pemakzulan (impeachment) terhadap kepala daerah melalui mosi tidak percaya. Sebab, tidak ada aturan yang memungkinkan masyarakat dapat secara langsung meng-impeach kepala daerah. Namun, DPRD bisa mengusulkan pemberhentian kepala daerah dan wakil kepala daerah kepada Presiden jika memenuhi ketentuan Pasal 29 atau diberhentikan sementara oleh Presiden apabila melakukan tindak pidana kejahatan (Pasal 3032).

Namun dalam prakteknya, penyelenggaraan pemerintahan daerah seringkali diwarnai dengan konflik politik antara kepala daera dan DPRD. Konflik politik yang terjadi pun tidak jarang mengganggu jalannya penyelenggaraan pelayanan publik bagi masyarakat. Salah satu kasus konflik politik antara kepala daerah dan DPRD yang banyak mendapat perhatian dari publik adalah konflik politik yang terjadi antara Gubernur DKI Jakarta, Basuki Tjahja Purnama (atau sering disapa Ahok) dengan DPRD DKI Jakarta dalam proses penetapan ABPD DKI Jakarta tajun anggaran 2015. Konflik ini bermula dari dugaan adanya dana "siluman" dalam RAPBD DKI Jakarta tahun 2012 sebesar 12,1 trilyun rupiah, pada saat pembahasan di DPRD. Konflik ini pun semakin dalam, ketika Gubernur Ahok melaporkan adanya dugaan dana "siluman" dalam APBD yang ditetapkan oleh DPRD kepada Komisi Pemberantasan Korupsi (KPK) dan Kepolisian. Begitu juga sebaliknya, DPRD DKI Jakarta juga melaporkan Gubernur DKI ke Mabes Polri terkait kasus tersebut. Dalam hal kewenangannya, DPRD DKI Jakarta juga membentuk Panitia Angket Kasus Dana "Siluman" APBD DKI Jakarta 2015. Konflik inipun akhirnya semakin meluas hingga pada persoalan rasisme dan upaya-upaya penggiringan opini publik oleh kedua lembaga politik di DKI Jakarta tersebut.

Konflik politik dalam penetapan APBD DKI Jakarta tahun anggaran 2015 inipun berdampak pada terlambatnya anggaran pencairan APBD, itu artinya pelayanan publik di DKI Jakarta tidak tepat waktu, termasuk anggarananggaran untuk kebutuhan dasar warga DKI seperti pendidikan, kesehatan, dan pelayanan dasar lainnya. Hal inilah yang menarik untuk dikaji secara lebih mendalam, mengingat sesuai amanah UU, antara Gubernur dan DPRD harus searah dan sejalan dalam menetapkan setiap kebijakan publik. Konflik politik antara keduanya tidak hanya berdampak pada stabilitas politik local, namun yang lebih penting dari itu adalah terbengkalainya pelayanan masyarakat, khususnya pelayanan dasar yang mesti tepat waktu.

Kehadiran Basuki Tjahaya Purnama sebagai Gubernur DKI Jakarta, yang menggantikan Joko Widodo, di pertengahan tahun 2014, memang sudah memanaskan suasan politik di DKI Jakarta. Terlebih lagi ketika Ahok menyatakan keluar dari Partai Gerindra yang telah mengusungnya dalam Pemilukada DKI Jakarta tahun 2012. Secara kalkulasi politik, Ahok hanya didukung oleh PDIP setelah Partai Gerindra mencabut dukungan politiknya di 
DPRD DKI Jakarta, itu artinya 9 fraksi di DPRD DKI Jakarta menjadi oposisi Pemerintahan Gubernur Ahok.

Memang dalam pembuatan atau perumusan suatu kebijakan, apalagi kebijakan itu berupa peraturan/peraturan daerah, bukanlah suatu proses yang sederhana dan mudah. Hal ini disebabkan karena terdapat banyak faktor atau kekuatan-kekuatan yang berpengaruh terhadap proses pembuatan kebijakan tersebut. Suatu kebijakan daerah (peraturan daerah) dibuat bukan untuk kepentingan politik (guna mempertahankan status quo pembuat keputusan) tetapi justru untuk meningkatkan kesejahteraan hidup anggota masyarakat secara keseluruhan (Irfan, 1997).

Untuk memperjelas makna yang terkandung dalam perumusan kebijakan, Charles Lindblom (Abdul Wahab, 1990), menuturkan bahwa pembuatan kebijakan negara (public policy marking) itu pada hakekatnya merupakan "an extermely complex, analytical and politica process to which there is no beginning or end, and the boundaries of which are mosed uncertain. Somehow a complex set of forces that we call policy making all taken together, produses effects called policies." (Merupakan proses politik yang amat kompleks dan analisis, di mana tidak mengenal saat dimulai dan diakhirinya, dan batas-batas dari proses itu sesungguhnya yang paling tidak pasti. Serangkaian kekuatan-kekuatan yang agak kompleks yang disebut sebagai pembuatan kebijakan negara itulah yang membuahkan hasil yang disebut kebijakan).

Ketidakharmonisan antara pelaksana pemerintahan daerah, Gubernur dan DPRD ini menandai adanya konflik politik antara Kepala Daerah dengan DPRD. Padahal seharusnya pola hubungan antara eksekutif dengan legislatif antara lain hubungan pola harmonis, kolutif, kolaboratif, dominatif, dan konflik. Jenis hubungan tersebut dapat dipengaruhi 2 (dua) hal, pertama, kemampuan Kepala Daerah dalam menjalin hubungan/komunikasi politik dengan DPRD, jika Kepala Daerah dapat melakukan komunikasi politik dengan baik dengan anggota DPRD maka potensi konflik dapat diredam. Kedua, dukungan kursi yang dipunyai terutama partia politik pendukung saat pencalonan, semakin besar dukungan parpol pengusung maka potensi konflik akan semakin kecil demikian sebaliknya jika parpol pendukung semakin kecil maka potensi konflik semakin besar.

Apabila dilihat dari perspektif kekuasaan pemerintahan daerah, konsekuensi dari sistem pemilihan langsung pada lembaga legislatif (DPR/DPRD) dan eksekutif (Presiden/Kepala Daerah) menghasilkan lembaga politik yang memiliki legitimasi kuat mengemban amanah rakyat. Hal ini tentu mengharapkan adanya keseimbangan kekuasaan dalam penyelenggaraan pemerintahan daerah. Namun masalahnya keseimbangan ini acapkali menimbulkan inmobilisasi dan kemandegan. Para anggota legislatif lokal, terutama yang mewakili partai-partai yang kuat yang menawarkan berbagai alternatif kebijakan politik dapat menggunakan legitimasi demokrasi yang kuat. Tuntutan itu dilontarkan bila mayoritas legislatif menentukan suatu pilihan politik yang berlawanan dengan pilihan eksekutif. Hal ini seperti yang terjadi pada kasus konflik antara Gubernur dan DPRD DKI Jakarta dalam proses 
penetapan APBD 2015. Dalam keadaan seperti ini tentu sulit menentukan siapa yang memiliki tuntutan lebih kuat untuk berbicara atas nama rakyat, karena keduanya memperoleh legitimasi dari rakyat melalui proses demokrasi langsung.

Dalam kondisi seperti ini konflik selalu timbul dan kadang-kadang merusak. Tidak ada mekanisme kelembagaan dan dasar konstitusi yang dapat digunakan untuk menuntaskan penyelesaian konflik seperti ini. Karena itu menarik untuk diteliti bagaimana dilema kekuasaan antara pihak eksekutif (Gubernur) dan legislatif (DPRD) dalam mengemban tugas konstitusionalnya untuk menciptakan pemerintahan daerah yang efektif, namun di saat yang sama kedua pihak memiliki perbedaan partai politik, posisi kelembagaan, dukungan kewenangan kelembagaan dan legitimasi publik.

Uraian di atas memberikan gambaran jelas bahwa penyelenggaraan pemerintaha daerah rentan akan konflik politik antara pihak eksekutif dan legislatif. Pertarungan tersebut terjadi dengan menggunakan instrumen kewenangan masing- masing, baik Gubernur maupun DPRD DKI Jakarta. Secara konseptual, konflik politik antara Gubernur dan DPRD DKI Jakarta di sini mangacu pada pertentangan antar kolompok (kubu) dalam pemerintahan, dengan mempergunakan isu-isu publik yang menyangkut kepentingan banyak orang yang lebih mengarah kepada adanya relasi kekuasaan atau proses pengambilan keputusan (Rauf, 2001). Dalam hal ini, konflik politik disebabkan oleh dua hal utama, yakni perbedaan kepentingan, serta perebutan sumber daya (resources) yang langka atau sangat terbatas, seperti jabatan dan kekuasaan politik. Dalam konflik politik, pihak-pihak yang terlibat merupakan mereka yang survive dan memiliki akses terhadap sesuatu yang diperebutkan (Oberg dan Strom, 2008).

Untuk dapat memahami konflik yang terjadi dalam penetapan APBD DKI 2015 pada pemerintahan daerah DKI Jakarta, maka yang pertama adalah mengetahui bentuk pola kekuasaaan yang ada pada aktivitas politik ini. Konflik ini tidak hanya akan memberikan gambaran mengenai jumlah kekuatan yang dimiliki oleh pihak-pihak yang berinteraksi, juga secara lebih dalam akan mampu melihat kepentingan-kepentingan yang ada di dalamnya, baik itu yang nyata maupun kepentingan tersembunyi yang dimiliki pihak yang ada dalam pusaran konflik kekuasaan tersebut.

Hal lain yang menarik untuk dikaji adalah bagaimana cara masingmasing pihak melakukan kewenanganya dalam konflik, hal ini berarti bagaimana cara pihak- pihak yang terlibat dalam pembuatan dan penetapan APBD. DPRD DKI Jakarta menggunakan kekuasaannya untuk dapat mencapai dan mempertahankan kepentingannya. Dua aktor utama yang berwenang untuk secara bersama-sama merumuskan dan menetapkan APBD DKI Jakarta tahun 2015. Pemerintah daerah dan DPRD, secara legal formal memiliki kedudukan dan posisi kekuasaan yang sama karena keduanya merupakan hasil dari pilihan rakyat secara langsung. Namun karena kepentingan yang berbeda, maka dapat terjadi konflik pada dua lembaga daerah ini. Sehingga bagaimana kedua lembaga ini melakukan interaksi dan konflik kepentingan dan bagaimana menjelaskan relasi saling mempengaruhi antara pihak-pihak yang berkepentingan dalam proses pembahasan dan penetapan APBD 2015. 
Urgensitas kajian tentang konflik politik antara kepala daerah (gubernur) dan DPRD dalam penyelenggaraan pemerintahan daerah adalah sebagai bentuk evaluasi terhadap penyelenggaraan sistem otonomi daerah, karena dalam penyelenggaraan otonomi daerah di Indonesia, kedua lembaga tersebut (Gubernur dan DPRD), merupakan unsur penyelenggara pemerintahan daerah yang tidak dapat dipisahkan. Keduanya merupakan mitra kerja yang mesti sejalan dan searah dalam penyelenggaraan pemerintahan daerah. Dengan adanya penelitian tentang konflik politik akan dapat dianalisa penyebab terjadinya konflik politik, dan sekaligus menghasilkan model penyelesaiannya. Dengan demikian penelitian ini dapat memberikan sumbangsih gagasan akan pencegahan adanya konflik politik lembaga eksekutif dan legislatif di tingkat lokal. Dengan memperhatikan dinamika yang berkembang dan interaksi antara eksekutif dan legislatif, sebagaimana terurai di atas, maka peneliti tertarik untuk melakukan penelitian tentang: "Konflik Politik Antara Gubernur dan DPRD DKI Jakarta Dalam Proses Penetapan APBD 2015".

\section{Rumusan Masalah}

Dari rumusan masalah tersebut, penulis membuat pertanyaan penelitian sebagai berikut:

a. Mengapa terjadi konflik politik antara Gubernur dan DPRD DKI Jakarta dalam proses penetapan APBD 2015?

b. Apa dampak konflik politik antara Gubernur dan DPRD DKI Jakarta dalam proses penetapan APBD 2015 terhadap penyelenggaraan pemerintahan daerah?

c. Bagaimana pola yang digunakan dalam penyelesaian konflik politik antara Gubernur DPRD DKI Jakarta dalam proses penetapan APBD 2015?

\section{TINJAUAN PUSTAKA}

\section{Teori Konflik Politik}

Istilah konflik untuk pertama kali dikenal dalam ilmu sosiologi, yang asal katanya dari bahasa Latin "configure", yang berarti "saling memukul". Dalam kajian sosiologi, konflik diartikan sebagai suatu proses sosial antara dua orang atau lebih (bisa juga kelompok), di mana salah satu pihak berusaha menyingkirkan pihak lain dengan menghancurkannya atau membuatnya tidak berdaya. Dalam kaitan ini Ralf Dahrendorf mengartikan konflik sebagai ketegangan dalam pengambilan keputusan pada berbagai pilihan, dan terkadang diwujudkan dalam konfrontasi antar kekuatan sosial. Dalam arti luas, konsep konflik telah ditarik dan dipergunakan untuk menggambarkan setiap perselisihan yang dihasilkan oleh setiap aspek dari situasi sosial (Prihatmoko, 2008).

Untuk lebih mudah mengidentifikasi konflik dalam masyarakat, setidaknya ada empat persyaratan agar dapat dikategorikan konflik dalam masyarakat, yaitu: Pertama, terdapat dua atau lebih pihak (individu atau kelompok) yang terlibat. Kedua, mereka terlibat dalam tindakan-tindakan yang saling memusuhi. Ketiga, mereka menggunakan perlakuan-perlakuan kekerasan yang bertujuan untuk 
menghancurkan, melukai, dan menghalang-halangi lawannya. Keempat, reaksi pertentangan ini bersifat terbuka sehingga dapat dideteksi dengan mudah oleh orang lain (observer) (Gurr dalam Haryanto, 1990). Selanjutnya Dahrendoef menunjukkan ciri-ciri penyebab terjadinya konflik, yaitu: pertama, karena tidak tercapainya kepentingan dari individu maupun kelompok (party). Kedua, keinginan memperbarui kepentingan. Ketiga, adanya rasa cemburu, ketidaksenangan kesuksesan atas kelompok komunitas tertentu (Dahrendoef, 1986).

Dari pemaparan di atas dapat dijelaskan bahwa pada tingkatan apapun, konflik yang terjadi pada dasarnya melibatkan unsur-unsur dasar yang khas. Kemunculannya dipicu oleh beragam faktor. Dalam manajemen konflik, maka perlu diketahui apa yang memicu konflik, siapa saja yang terlibat dalam konflik, apa isu yang disengketakan, bagaimana strategi yang dipakai masing-masing pihak yang berkonflik untuk mencapai kemenangan, peluang konflik untuk meluas/mereda, dan apa konsekuensi dari konflik yang terjadi. Pengumpulan informasi yang akurat seputar pertanyaan di atas diharapkan dapat menghasilkan analisa yang akurat dalam memahami suatu permasalahan, dan meraih tujuan yang ingin dicapai oleh pihak-pihak yang berkonflik.

Adapun dalam terminologi ilmu politik, istilah konflik seringkali dikaitkan dengan kekerasan seperti kerusuhan, kudeta, terorisme, dan refolusi. Konflik mengandung pengertian "benturan" seperti perbedaan pendapat, persaingan, dan pertentangan antar individu dan individu, kelompok dan kelompok, antara individu dan kelompok atau pemerintah (Surbakti, 1992). Dalam pandangan Maswadi Rauf, konflik politik mempunyai keterkaitan dengan negara/pemerintah, para pejabat politik/pemerintahan, politisi, dan yang berhubungan dengan pengambilan kebijakan/keputusan. Konflik politik menekankan pada pertentangan antar kolompok (kubu) dengan mempergunakan isu-isu publik yang menyangkut kepentingan banyak orang yang lebih mengarah kepada adanya relasi kekuasaan atau proses pengambilan keputusan (Rauf, 2001). Dalam konflik politik yang menjadi aktor utama adalah elit politik karena merekalah yang memiliki relasi pada pusaran kekuasaan. Ini sejalan dengan asumsi dasar Gaetano Mosca yang mengatakan bahwa dalam suatu komunitas masyarakat terdiri dari sejumlah kecil elit politik yang memiliki kekuasaan politik (the ruling class) dan sejumlah besar masyarakat yang secara umum berada dalam posisi diperintah (the ruled class) (Varma, 2001).

Di samping itu juga konflik politik disebabkan oleh dua hal. Konflik politik itu mencakup kemajemukan horizontal dan kemajemukan vertical. Adapun pengertian kemajemukan horizontal ialah struktur masyarakat yang majemuk secara cultural, seperti suku bangsa, daerah, agama, dan ras. Sedangkan kemajemukan horizontal cultural dapat menimbukan konflik karena masingmasing unsur budaya berupaya mempertahankan identitas dan karakteristik budayanya dari ancaman budaya lain. Apabila terdapat didalam masyarakat yang mempunyai berciri demikian ini, apabila belum ada suatu konsensus nilai yang menjadi pegangan bersama, konflik politik karena benturan budaya akan menimbulkan perang saudara ataupun gerakan separatism (faham politik yang 
menekankan kebebasan). Untuk itu maka, kemajemukan horizontal social dapat menimbulkan konflik sebab masing-masing kelompok yang berdasarkan pekerjaan dan profesi serta tempat tinggal tersebut memiliki kepentingan berbeda bahkan saling bertentangan (Ali, 2006).

Sementara itu, kemajemukan vertical ialah struktur masyarakat yang berlawanan menurut kepemilikan kekayaan, pengetahuan, dan kekuasaan. Dengan demikian, kemajemukan vertical dapat menimbulkan konflik oleh karena sebagian besar masyarakat tidak memiliki atau hanya memiliki sedikit kekayaan, pengetahuan, dan kekuasaan akan memiliki kepentingan yang bertentangan dengan kelompok kecil masyarakat yang mendominasi. Sehingga, kekayaan, pengetahuan, dan kekuasaan merupakan penyebab utama tmbulnya suatu konflik politk. Apabila dalam kenyataannya terdapat perbedaan kepentingan karena kemajemukan horizontal dan vertical tidak dengan sendirinya menimbulkan konflik. Hal ini disebabkan adanya fakta terdapat sejumlah masyarakat yang menerima perbedaan-perbedaan tersebut. Perbedaan-perbedaan masyarakat ini baru menimbulkan konflik, apabila kelompok tersebut memperebutkan sumber yang sama, seperti kekuasaan, kesempatan, dan lain sebagainya. Konflik terjadi manakalah terdapat benturan kepentingan. Dalam pengertian lain dapat dikemukakan konflik terjadi jika pada pihak yang merasa diperlakukan tidak adil atau manakala pihak berprilaku menyentuh "titik kemarahan" pihak lain. Dengan kata lain, perbedaan kepentingan karena kemajemukan vertical dan horizontal merupakan kondisi yang harus ada bagi timbulnya konflik, tetapi perbedaan kepentingan itu bukan kondisi yang memadai untuk menimbulkan konflik (Ali, 2006).

Dengan demikian, konflik politik dapat dipahami dari berbagai dimensi dalam melihat faktor penyebab, motif dan kepentingan-kepentingan politiknya. Pertama, dari segi pengertiannya, konflik diartikan sebagai pertentangan yang terbuka antar kekuatan kekuatan politik (kubu) yang memperebutkan kekuasaan sehingga dapat dilihat oleh orang luar. Pengertian konflik di sini merujuk kepada hubungan antar kekuatan politik (kelompok/kubu dan individu yang memiliki jaringan dalam struktur kekuasaan) yang merasa memiliki sasaran-sasaran yang tidak sejalan. Kedua, sasaran-sasaran yang tidak sejalan sesungguhnya menunjukkan adanya perbedaan kepentingan. Oleh karena itu, kepentingan dapat digunakan sebagai cara untuk melihat perbedaan motif di antara kelompok yang saling bertentangan, baik dalam sebuah kelompok skala besar, maupun kecil. Perbedaan kepentingan setidaknya akan menunjukkan motif mereka berkonflik. Motivasi seseorang atau kelompok untuk merebut kekuasaan selain dia ingin berkuasa, mereka juga ingin menguasai sumber daya ekonomi.

Konflik politik dapat dibagi menjadi dua tipe, yaitu konflik positif dan konflik negatif. Konflik positif ialah konflik yang tidak mengancam eksistensi sistem politik, yang biasanya disalurkan lewat mekanisme penyelesaian konflik yang disepakati bersama dalam konstitusi. Mekanisme yang dimaksud ialah lembaga-lembaga demokrasi, seperti: partai politik, badan-badan perwakilan rakyat, pengadilan, pemerintah, pers dan forum-forum terbuka yang lain. Tuntutan akan perubahan yang diajukan oleh sejumlah kelompok masyarakat melalui 
lembaga-lembaga itu merupakan contoh konflik positif. Sebaliknya, konflik negatif ialah konflik yang dapat mengancam eksistensi sistem politik yang biasanya disalurkan melalui cara-cara nonkonstitusional, seperti kudeta, separatisme, terorisme, dan revolusi (Surbakti, 1999).

Sehubungan dengan konflik positif dan negatif maka sesungguhnya masyarakat, dapat dikelompokkan secara umum menjadi dua tipe. Pertama, masyarakat yang mapan. Artinya, masyarakat yang memiliki dan mendayagunakan struktur kelembagaan yang diatur dalam konstitusi. Konflik yang dianggap positif dalam masyarakat ini berupa konflik yang disalurkan melalui struktur kelembagaan, sedangkan konflik yang negatif berupa tindakan yang menentang struktur yang ada dan yang disalurkan melalui cara-cara diluar struktur kelembagaan yang ada. Kedua, masyarakat yang belum mapan. Artinya, masyarakat yang belum memiliki struktur kelembagaan yang mendapat dukungan penuh dari seluruh masyarakat. Biasanya struktur kelembagaan yang diatur dalam konstitusi, selain tidak didukung oleh sebagian masyarakat, juga belum berfungsi sebagimana mestinya. Konflik yang dianggap positif dalam masyarakat ini seringkali justru konflik yang disalurkan melalui cara-cara diluar struktur kelembagaan yang ada karena dianggap lebih efektif. Kategorisasi itu tentu lebih bersifat analitis (lebih kurang) daripada pengelompakan secara hitam putih. Sebab dalam kenyataan, konflik dan dukungan masyarakat terhadap sistem yang ada (struktur kelembagaan) tidak sederhana itu. (Surbakti, 1999).

Dalam masyarakat yang sedang mengalami konflik pada umumnya terdapat dua kelompok besar yang terlibat serta memiliki perspektif yang berbeda dalam meraih kepentingannya. Paul M. Collier dalam penelitiannya, disponsori oleh Bank Dunia, yang dilakukan di negara-negara yang sedang dilanda konflik yang terus-menerus berlangsung tanpa penyelesaian, seperti beberapa negara di Afrika dan Asia Tenggara, termasuk Indonesia menyimpulkan bahwa konflik yang berlangsung terus-menerus, dan tidak menemukan solusinya yang tepat, melahirkan dua perspektif yaitu greed dan grievance. Dalam perspektif greed, konflik adalah sesuatu event yang menguntungkan karena adanya peluang melakukan eksploitasi masyarakat melalui propaganda politik. Dalam situasi konflik itu segala cara yang dapat dilakukan untuk mendatangkan keuntungan, seperti halnya melakukan mobilisasi massa dan manipulasi fakta dalam mediskreditkan lawan-lawan politiknya (Collier, 2003).

Sementara dalam perspektif grievance konflik dipandang sebagai ketidakadilan karena dapat merugikan, terdzalimi serta dapat mengancam eksistensinya. Mereka yang mengalami ketidakadilan dan rasa kekecewaan yang mendalam, akan melakukan tindakan emergency untuk menyelamatkan diri dari berbagai ancaman, yaitu mau tidak mau harus melakukan perlawanan dengan segala strategi dan resiko (Collier, 2003). Oleh karena itu, konflik, di samping tidak menguntungkan (disadvantaged), akan menggiring ke arah marjinalisasi dan diskriminatif dalam lingkungan politiknya. Hal ini bisa terjadi karena menyangkut ancaman eksistensi masa depan, sehingga mereka berupaya melakukan perlawanan dan mencari tindakan alternatif lain untuk merebut dan memeroleh kepentingan politiknya untuk hidup yang lebih layak. Setiap kelompok 
masyarakat kerapkali mengklaim bahwa mereka berjuang untuk rakyat, sehingga isu-isu yang mereka tebarkan adalah isu publik (kebijakan publik) (Haryanto, 1990).

Hasil penelitian Collier juga menjelaskan bahwa penyebab terjadinya konflik politik disebabkan oleh dua hal utama, yakni perbedaan kepentingan dan adanya persaingan dalam memperebutkan resources yang langka atau sangat terbatas, seperti jabatan politik (Collier, 2003). Pendapat yang sama juga dikemukakan oleh Oberg dan Strom (2008), bahwa resources bisa menjadi sumber konflik, jika terjadi ketimpangan dalam pendistribusiannya. Selanjutnya mereka menjelaskan bahwa "disputes over the control over resources, or the distribution of resources, are potensial reasons for civil conflict" (Oberg dan Strom, 2008).

Dalam kaitannya dengan sebab-sebab terjadinya konflik politik, Michel E. Brown menjelaskan bahwa konflik politik terjadi disebabkan oleh banyak faktor. Brown membedakan underlying causes of conflict dari the proximate causes of conflict. Maksudnya Brown membedakan antara sebab-sebab utama konflik dan sebab-sebab pemicu muncul konflik politik. Secara lebih lengkap dapat dilihat pada tabel 1 di bawah ini.

Tabel 1. Sebab-Sebab Utama dan Sebab-sebab Pemicu Konflik Politik

\begin{tabular}{|l|l|}
\hline \multicolumn{1}{|c|}{ Sebab Utama (Underlying Causes) } & \multicolumn{1}{|c|}{ Sebab Pemicu (Proximate } \\
\hline Lembaga politik yang diskriminatif & Transisi politik \\
\hline Ideologi nasional yang eksklusif & Ideologi eksklusif yang \\
\hline Politik antar kelompok & $\begin{array}{l}\text { Persaingan antar kelompok yang } \\
\text { semakin tajam }\end{array}$ \\
\hline Politik elit & $\begin{array}{l}\text { Pertarungan kepimpinan yang } \\
\text { semakin tajam }\end{array}$ \\
\hline
\end{tabular}

Lebih sederhana, Buzan berpendapat jika aktor-aktor atau kelompok ingin eksis dan survive, maka mereka yang berkonflik harus melakukan sekuritisasi isu- isu yang berkaitan dengan grievance. Dalam pandangan Buzan, strategi sekuritisasi adalah sangat penting untuk meraih tujuan atau kepentingan aktor yang bersifat greedy (Buzan, 1998). Alfian dalam pengantar buku T.B. Bottomore, Elit dan Masyarakat, mengatakan bahwa studi elit senantiasa terkait dengan konsep kepentingan. Kajian-kajian tentang dinamika elit politik, pastilah merupakan kajian-kajian tentang persinggungan dan persaingan kepentingan (Bottomore, 2006).

Dalam kaitan ini, Keller menjelaskan bahwa studi tentang elit memusatkan perhatian pada empat hal. Pertama, anatomi elit berkenaan dengan siapa, berapa banyak dan bagaimana para elit itu muncul. Kedua, fungsi elit berkenaan dengan apa tanggungjawab sosial elit. Ketiga, pembinaan elit menyangkut tentang siapa yang mendapatkan kesempatan menjadi elit, imbalan apa yang mereka terima, dan kewajiban-kewajiban apa yang menunggu mereka. Keempat, keberlangsungan 
(bertahannya) elit berkenaan dengan bagaimana dan kenapa para elit itu dapat bertahan, serta bagaimana dan kenapa diantara mereka hancur atau tidak dapat bertahan (Keller, 1996).

Pengembangan teori konflik sebagai sebuah fenomena politik mempunyai berbagai dimensi yang melahirkan berbagai perspektif dalam melakukan analisa dan mencari solusi. Dimensi konflik perlu dipahami sebagai landasan analisis dalam melakukan resolusi konflik atas berbagai fenomena politik yang terjadi salah satunya dalam mengamati konflik politik yang terjadi antara Gubernur dengan DPRD Provinsi DKI Jakarta yang di motori oleh sejumlah aktor politik dari partai yang menjadi lawan dalam memperebutkan kepentingan-kepentingan politik.

Beranjak dari fokus penelitian, maka dibutuhkan sebuah teori yang tepat dan relevan untuk dijadikan sebagai pisau analisa dalam penelitian ini. Dari banyak teori yang dikemukakan oleh sarjana politik, penulis lebih menggunakan konsep yang dikemukakan oleh Paul M. Collier, yang menjelaskan bahwa konflik politik terjadi disebabkan oleh dua faktor utama, yakni perbedaan kepentingan, dan perebutan sumber daya (resources) yang langka atau sangat terbatas, seperti jabatan dan kekuasaan politik. Dalam konflik politik, pihak-pihak yang terlibat merupakan mereka yang survive dan memiliki akses terhadap sesuatu yang diperebutkan (Collier, 2003).

Konflik memang tidak bisa dihindari oleh setiap aktor, namun yang paling penting adalah cara untuk menyelesaikan konflik agar ancaman (threat) bisa menjadi kesempatan (oppurtunity) dan bahaya timbulnya konflik terbuka secara meluas dilokalisasi dengan membangun suatu model pencegahan dan penanggulangan dini. Suatu kebiasaan khas dalam konflik adalah memberikan prioritas yang tinggi guna mempertahankan kepentingan pihaknya sendiri, sehingga pihak-pihak yang berkonflik biasanya cenderung melihat kepentingan mereka sebagai kepentingan yang bertentangan secara diametrikal, untuk itulah perlu dicari cara penyelesaian yang cepat agar tidak berdampak lebih luas.

Untuk itu, menurut Dahrendorf (1986) perlu diadakan suatu peraturan pertentangan yang mensyaratkan tiga faktor. Pertama, kedua kelompok yang terlibat dalam pertentangan harus mengakui pentingnya dan nyatanya situasi pertentangan dan dalam hal ini, mengakui keadilan fundamental dari maksud pihak lawan. Pengakuan adilnya maksud lawan tentu saja bukan berarti bahwa subtansi kepentingan lawan harus diakui sebagai adil dari awal. Pengakuan di sini berarti bahwa kedua kelompok yang bertentangan menerima untuk apa pertentangan itu, yakni menerimanya sebagai suatu hasil pertumbuhan yang tak terelakkan. Syarat kedua, adalah organisasi kelompok-kelompok ke pentingan. Selama kekuatan-kekuatan yang bertentangan itu terpencar-pencar dalam kesatuan yang kecil yang masing- masing erat ikatannya, peraturan pertentangan tidak akan efektif. Syarat ketiga, adanya keharusan bagi kelompok- kelompok yang berlawanan dalam pertentangan sosial menyetujui aturan formal tertentu yang menyediakan kerangka hubungan bagi mereka.

Penyelesaian konflik sendiri merupakan suatu proses analisis dan penyelesaian masalah yang mempertimbangkan kebutuhan-kebutuhan individu 
dan kelompok seperti identitas dan pengakuan juga perubahan-perubahan institusi yang diperlukan untuk memenuhi kebutuhan-kebutuhan. Dalam setiap konflik selalu dicari jalan penyelesaian. Konflik terkadang dapat saja diselesaikan oleh kedua belah pihak yang bertikai secara langsung. Namun tidak jarang pula harus melibatkan pihak ketiga untuk menengahi dan mencari jalan keluar (Hermawan, 2007). Istilah lain yang juga sering dikenal adalah manajemen konflik, yang merujuk pada suatu pendekatan yang berorientasi pada proses yang mengarahkan pada bentuk komunikasi (termasuk tingkah laku) dari pelaku maupun pihak luar dan bagaimana mereka mempengaruhi kepentingan (interest) dan interpretasi (Ross, 1993).

Salah satu konsep pengelolaan konflik yang sederhana dikemukakan oleh Simon Fisher dan Kartikasari (2001), bahwa penyelesaian suatu konflik yang terjadi dapat dilakukan dengan tiga cara. Pertama, negosiasi, merupakan suatu proses yang memungkinkan pihak-pihak yang berkonflik untuk mendiskusikan berbagai kemungkinan pilihan dan mencapai penyelesaian melalui interaksi tatap muka. Proses dalam kaitan ini mengacu pada perundingan dua belah pihak atau lebih yang masing-masing memiliki sesuatu yang dibutuhkan oleh pihak lainnya untuk mencapai kesepakatan yang saling menguntungkan. Dalam hal ini Gubernur dan DPRD DKI Jakarta melakukan perundingan secara informal dalam rangka menemukan titik temu yang saling menguntungkan kedua belah pihak, yang berkaitan dengan proses penetapan APBD DKI Jakarta 2015. Dengan memahami proses perundingan ini diharapkan akan menghasilkan temuan-temuan tentang apa saja yang diinginkan oleh kedua belah pihak terhadap program ini.

Kedua, mediasi, yaitu suatu proses interaksi yang dibantu oleh pihak ketiga sehingga pihak-pihak yang berkonflik menemukan penyelesaian yang mereka sepakati sendiri. Penyelesaian konflik melalui penengah (mediator) yang mencari jalan keluar secara mufakat dari para pihak yang berkonflik. Dalam proses ini, mediator tidak memiliki kewenangan memutus atau memaksakan sebuah penyelesaian. Ciri utama proses mediasi adalah perundingan yang esensinya sama dengan proses musyawarah atau konsensus. Sesuai dengan hakikat perundingan atau musyawarah atau konsensus, maka tidak boleh ada paksaan untuk menerima atau menolak sesuatu gagasan atau penyelesaian selama proses mediasi berlangsung. Proses penyelesaian dengan pola ini dimungkinkan terjadi pada penyelesaian konflik antara Gubernur dan DPRD DKI dalam proses penetapan APBD DKI Jakarta 2015. Mediator tentu berasal dari elit politik partai yang memiliki pengaruh terhadap kedua belah pihak yang berkonflik. Ketiga, arbitrase atau perwalian dalam sengketa, tindakan oleh pihak ketiga yang diberi wewenang untuk memutuskan dan menjalankan suatu penyelesaian. Proses penyelesaian dengan pola ini dimungkinkan terjadi pada penyelesaian konflik antara Gubernur dan DPRD DKI dalam proses penetapan APBD DKI Jakarta 2015.

Dari ketiga pola penyelesaian konflik di atas, penelitian ini akan lebih memfokuskan pada pola penyelesaian secara negosiasi, mediasi, dan arbitrase. Dengan memahami pola penyelesaian konflik antara Gubernur dan DPRD DKI Jakarta diharapkan dapat menemukan berbagai data dan informasi tentang hasil- 
hasil kesepakatan antarkedua belah pihak, yang pada akhirnya dapat menguatkan alasan faktor-faktor yang melatarbelakangi konflik tersebut.

Secara tradisional, tugas penyelesaian konflik adalah membantu pihakpihak yang merasakan situasi yang mereka alami sebagai sebuah situasi zero sum (keuntungan diri sendiri adalah kerugian pihak lain). Agar melihat konflik sebagai keadaan non-zero-sum (di mana kedua belah pihak dapat memperoleh hasil atau keduanya sama-sama tidak memperoleh hasil) dan kemudian membantu pihak-pihak yang berkonflik berpindah ke arah hasil yang positif. Untuk menciptakan hasil non-zero-sum, diperlukan adanya pihak yang berfungsi menyelesaikan konflik (Fisher dan Kartikasari, 2001).

\section{Teori Elit Politik}

Di dalam kehidupan bermasyarakat dapat ditemukan adanya perbedaan di dalam masyarakat. Perbedaan itu tidak hanya sebatas perbedaan yang bersifat fisik, tetapi juga perbedaan lainnya seperti bakat keterampilan dan kekayaan. Perbedaan tersebut dapat dinyatakan sebagai titik awal bagi munculnya kelompok-kelompok yang mempunyai keunggulan apabila dibandingkan dengan kelompok lainnya dalam suatu masyarakat yang sama. Anggota masyarakat yang mempunyai keunggulan pada gilirannya akan tergabung dalam suatu kelompok yang lebih dikenal dengan sebutan elit. Secara etimologi kata "elit" berasal bahasa Latin "eligere" yang berarti terpilih. Kata itu juga di gunakan di Perancis pada abad ke XIV yang mengandung pengertian "memilih" (Keller, 1995).

Terminologi elit, sebagaimana diungkapkan oleh Vilfredo Pareto, Gaetano Mosca, Suzanne Keller pemikir yang tergolong dalam elite theoritis memang menunjukan pada kelompok atau golongan yang ada di suatu masyarakat yang memiliki keunggulan atau superioritas apabila dibandingkan dengan kelompok atau golongan yang lainnya (Varma, 2001). Kata elite pada abad XVII digunakan untuk menggambarkan barang-barang dengan kualitas sempurna, penggunaan kata itu kemudian diperluas untuk merujuk kelompok-kelompok sosial yang unggul, misalnya unit-unit militer kelas satu atau tingkatan bangsawan yang tinggi. Sehubungan dengan hal tersebut, maka teori elit memandang bahwa setiap masyarakat terbagi dalam dua kategori yang luas yaitu sekelompok kecil manusia yang berkemampuan dan karenanya menduduki posisi untuk memerintah dan sejumlah besar massa yang ditakdirkan untuk diperintah. Menurut Hoover, bahwa elit politik meliputi semua pemegang kekuasaan dalam suatu bangunan politik. Dalam masyarakat terdapat dua kategori elit yaitu elit yang memerintah atau berkuasa dan elit yang tidak memerintah yang tidak berhubungan dengan pelaksanaan kekuasaan walaupun mereka itu memiliki pengaruh sosial yang penting (Bottomore, 2006).

Elit juga sering diartikan sebagai sekumpulan orang sebagai individu yang superior, yang berada dengan massa yang menguasai jaringan-jaringan kekuasaan adalah kelompok yang berada di lingkaran kekuasaan maupun yang sedang berkuasa (Mashad, 2005). Dalam hal stratifikasi masyarakat, Mosca dan Pareto membaginya ke dalam dua kategori yaitu (Varma, 2001):

1. Elit yang memerintah (governing elite). Kelas ini terdiri dari individu- 
individu yang secara langsung atau tak langsung mengendalikan dan memainkan peranan yang besar dalam pemerintahan.

2. Elit yang tidak memerintah (non-elite). Kelas ini terdiri dari individuindividu di luar sirkulasi pemerintahan.

Elit berdasarkan kajian teoritis yang dibangun awal-awalnya oleh Mosca Pareto, dan Michels mempunyai beberapa prinsip umum yaitu (Mas'oed \& MacAndrews, 2006) :

1. Adanya kekuasaan politik, seperti juga barang-barang sosial lainnya di distribusikan dengan tidak merata. Gagasan Pareto tentang orang berdasarkan pemilikan akan barang yang berwujud kekayaan, kecakapan atau kekuasaan politik merupakan hal yang menunjukkan prinsip itu.

2. Secara umum masyarakat dikategorikan ke dalam dua kelompok, mereka yang memiliki kekuasaan politik penting dan mereka yang tidak memilikinya.

3. Elit bersifat homogen, bersatu, dan memiliki kesadaran kelompok. Elit itu bukan merupakan penjumlahan orang saja tetapi individu yang berada dalam komunitas elit itu saling mengenal satu dengan yang lainnya, memiliki latar belakang yang sama (walaupun memiliki pandangan yang berbeda), memiliki nila-nilai yang sama dan kepentingan yang sama. dan anggotanya berasal dari satu lapisan masyarakat yang sangat terbatas

4. Elit mengatur sendiri kelangsungan hidupnya dan anggotanya berasal dari satu lapisan masyarakat yang sangat terbatas

5. Elit besifat otonom dan kebal akan gugatan dari siapapun yang diluar kelompoknya mengenai keputusan-keputusan yang dibuatnya. Semua persoalan politik penting diselesaikan menurut kepentingan atau tindakan kelompok.

Secara universal, Pareto dan Mosca memberikan konsep-konsep mengenai elit bahwa dalam setiap masyarakat senantiasa ada dan harus ada suatu kelompok minoritas yang memerintah masyarakat itu. Kelompok kecil itu merupakan kelas politik elit yang menduduki jabatan komando yang memerintah dan memegang kendali atas pemegang keputusan politik (Bottomore, 2006).

Mosca percaya dengan teori pergantian elit bahwa karakter yang membedakan elit adalah kecakapannya memimpin dan menjalankan kontrol politik, apabila elit yang memerintah tersebut kehilangan kecakapannya dan orang-orang di luar kelas elit tersebut menunjukan kemampuan yang lebih baik, maka terdapat segala kemungkinan bahwa kelas yang berkuasa akan dijatuhkan oleh kelas penguasa yang baru. Mosca sangat meyakini sejenis hukum yang menyatakan bahwa elit yang berkuasa tidak lagi mampu memberikan layananlayanan yang diperlukan oleh massa atau layanan yang diberikannya dianggap tidak lagi bernilai maka perubahan yang mengarah pada pergatian elit adalah sesuatu yang sulit untuk dihindari (Varma, 2001).

Perputaran elit menurut Mosca disebabkan karena kualitas intelektual dan moral individu namun hal ini tidak dipandang oleh Mosca sebagai faktor psikologis seperti pandangan Pareto tetapi karena dihasilkan oleh kondisi sosial, 
semangat pertempuran, tradisi dan lingkungan adalah hal yang membuat mereka harus berada di tempat yang tinggi, rendah atau rata-rata, dalam kelompok besar manusia manapun (Bottomore, 2006).

Sebagaimana Mosca, Pareto juga mengembangkan konsep pergantian (sirkulasi) elit. Pareto mengemukakan bahwa dalam setiap masyarakat ada gerakan yang tak dapat ditahan dari individu dan elit kelas atas yang melahirkan suatu peningkatan yang luar biasa pada unsur-unsur yang melorotkan kelas yang berkuasa, di pihak lain justru meningkatkan kualitas kelompok-kelompok lain. Ini menyebabkan semakin tersisihnya kelompok elit dalam masyarakat, dan akibatnya keseimbangan masyarakat menjadi terganggu. Selain itu, Pareto mengemukakan tentang berbagai jenis pergantian antar elit yaitu pergantian antar kelompok elit yang memerintah itu sendiri dan diantara elit dan penduduk lainnya (Bottomore, 2006).

Pergantian (sirkulasi) antar elit dan penduduk lainnya bisa berupa pemasukan: individu-individu dari lapisan yang berbeda ke dalam kelompok elit yang sudah ada atau individu dari lapisan bawah yang membentuk kelompok elit baru dan masuk ke dalam kancah perebutan kekuasaan dengan elit yang sudah ada. Dari gagasan Pareto ini dapat dikatakan bahwa kesempatan menjadi elit bukan hanya ditentukan oleh kecakapan-kecakapan seperti yang dikemukakan oleh Mosca, tetapi pada kemampuan membangun kekuatan gerakan lebih terorganisir untuk terlibat dalam pertarungan perebutan kekuasaan (Varma, 2001).

Perbedaan antara konsepsi Pareto dan Mosca ialah bahwa elit politik itu dibedakan dari elit-elit lain yang kurang dekat dihubungkan dengan penggunaan kekuasaan, meskipun mereka mungkin memiliki pengaruh sosial yang besar. Seperti halnya yang dapat kita lihat dengan seketika, gagasan tentang elit pada mulanya dipertentangkan dengan gagasan tentang sosial.

Elit sering diartikan sebagai individu-individu yang superior, yang berbeda dengan massa yang menguasai struktur dan jaringan-jaringan kekuasaan atau kelompok-kelompok sosial yang berada dalam lingkaran kekuasaan maupun yang sedang melaksanakan kekuasaan. Menurut Pareto menyebutkan bahwa elit politik terdiri dari dua komponen yaitu :

1. Elit Politik Lokal merupakan individu-individu yang menduduki jabatan politik (kekuasaan) di eksekutif dan legislatif yang dipilih melalui pemilu dan dipilih dalam proses yang demokratis di tingkat lokal. Mereka yang menduduki jabatan politik tinggi di tingkat lokal yang membuat kebijakankebijakan politik. Elit politik itu seperti: Gubernur, Bupati dan Walikota, Pimpinan DPRD, para anggota DPRD, dan pemimpin-pemimpin partai politik.

2. Elit Non-Politik Lokal adalah seseorang atau individu yang menduduki jabatan strategis dan mempunyai pengaruh untuk memerintah orang lain dalam lingkup masyarakat. Elit non-politik ini seperti: elit keagamanaan, elit organisasi kemasyarakatan dan kepemudaan serta profesi dan lain sebagainya.

Menurut Pareto dan Mosca secara prinsip mereka menyatakan pendapat bahwa disetiap sistem masyarakat baik struktur masyarakat yang masih bersifat 
tradisional ataupun tatanan masyarakat modern, pasti ditemukan sekelompok kecil minoritas individu yang memerintah anggota masyarakat lainnya.

Karl Menheim Berbeda dengan Pareto dan Mosca dalam membedakan tipe elit. Menurut Karl Menheim ada dua tipe elit yang berbeda secara prinsipil yaitu (Keller, 1995) :

1. Elit integratif, yang terdiri dari para pemimpin politik dan organisasi. Elit integratif mempunyai fungsi pokok yaitu mengintegrasikan sejumlah besar kehendak-kehendak perseorangan. Elit integratif berkerja melalui organisasi-organisasi politik formal.

2. Elit sublimatif yang terdiri dari para pemimpin moral-keagamaan, seni dan intelektual. Fungsi pokok dari elit sublimatif adalah mengadakan sublimasi tenaga kejiwaan manusia. Elit sublimatif bekerja melalui saluran-saluran yang lebih informal seperti golongan-golongan dan faksi-faksi .

\section{Teori Tentang Lembaga Legislatif}

Badan legislatif adalah lembaga yang "legislate" atau pembuat undangundang. Anggota-anggotanya dianggap mewakili rakyat, maka badan ini sering dinamakan Parlemen (di Indonesia disebut Majelis Permusyawaratan Rakyat). Ide pembentukan badan ini pada dasarnya bermula dari keperluan masyarakat akan hukum sebagai sarana untuk mengatur kehidupan bersama. Sejalan dengan ide tersebut, penguasa suatu negara secara keseluruhan membuat hukum atas nama rakyatnya dan memberlakukannya untuk menyelenggarakan kehidupan bersama (Sanit, 1985).

Sesungguhnya sejarah badan legislatif dapat ditelusuri sampai ke masa Yunani Kuno. Warga Athena yang menjadi Dewan Polis (Ekklesia) mempunyai kesempatan untuk mempengaruhi pembuatan kebijaksanaan, sekalipun sejumlah kecil di antara mereka mendominasi sidang dewan tersebut. Dewan yang mendampingi Badan Limaratus (Vouli ton Pentakosion) selaku badan eksekutif, bertugas mempertimbangkan keputusan bedan eksekutif tesebut dan mengeluarkannya dalam bentuk undang-undang melalui perdebatan antar anggota (Sanit, 1985).

Pada dasarnya tugas pokok dari badan legislatif (parlemen) di era modern ini adalah :

a. Fungsi legislatisi (membuat dan mengamandemen perundang-undangan).

b. Fungsi pengawasan (control)

c. Fungsi anggaran (budget)

a. Fungsi Legislasi (Membuat dan Mengamandemen Perundang-Undangan)

Fungsi utama dari badan legislatif adalah di bidang undang-undang, baik itu membentuk undang-undang maupun mengamandemen undang-undang. Melalui fungsi ini parlemen menunjukkan bahwa dirinya sebagai wakil rakyar dengan mengakomodir semua arpirasi dan kepentingan masyarakat yang diwakilinya ke dalam undang-undang yang dihasilkan. 
Akan tetapi dewasa ini, telah menjdai gajala umum bahwa titik berat di bidang legislatif (pembuat undang-undang) telah banyak bergeser ke badan eksekutif. Mayoritas perundang-undangan dirumuskan dan dipersiapkan oleh badan eksekutif, sedangkan badan legislatif tinggal membahas dan mengamandemennya. Sedangkan undang-undang yang dibuat atas inisiatif badan legislatif sedikit sekali jumlahnya dan jarang menyangkut kepentingan umum. Hal ini tidak mengherankan, sebab dalam Negara modern badan eksekutif bertanggungjawab atas peningkatan taraf hidup masyarakat dan karena itu harus memainkan peranan yang aktif dalam mengatur semua aspek kehidupan masyarakat. Kepemimpinannya tercermin dalam perundang-undangan yang dipersiapkannya.

\section{b. Fungsi Pengawasan (Control)}

Dengan semakin berkurangnya pengaruh badan legislatif di bidang legislatif, maka perannanya dibidang pengawasan bertambah menarik perhatian umum. Bentuk pengawasan oleh badan legislatif itu sendiri bermacam-macam. Apabila dilihat dari perkembangan sistem pemerintahan yang berkembang di berbagai Negara di dunia, maka dapat ditemukan beberapa bentuk pengawasan yang dapat dilakukan oleh lembaga parlemen terhadap kinerja (performance) pemerintah. Di antara bentuk-bentuk pengawasan yang penting adalah mengangkat dan memberhentikan kabinet; pengawasan terhadap pelaksanaan UUD dan UU; penentuan dan pengawasan anggaran dan keuangan Negara; melindungi hak milik dan kekayaan warga masyarakat dari pembebanan oleh Negara; menyelenggarakan debat publik mengenai kebijakan pemerintah, menyelenggarakan kegiatan dengar pendapat (hearing); serta meminta pertanggungjawaban Kepala Pemerintahan (Asshiddiqie, 2001).

Dalam melaksanakan tugas dan kegiatannya itu, palemen biasanya dilengkapi dengan hak-hak sebagai berikut : Hak interpelasi dan pertanyaan, hak penyelidikan terhadap kasus dugaan pelanggaran oleh pemerintah; hak resolusi atau pernyataan pendapat; hak mengingatkan atau memorandum; hak bertanya; hak mengusulkan untuk dilaksanakannya hak-hak lembaga parlemen hak protokol; serta hak kekebalan (imunitas) (Asshiddiqie, 2001).

\section{c. Fungsi Anggaran (Budget)}

Parlemen yang merupakan badan perwakilan rakyat, maka sudah seharusnya badan ini berwenang menentukan pemasukan dan pengeluaran uang Negara yang pada hakekatnya adalah uang rakyat. Baik pembelanjaan Negara yang diambil dari pajak sebagai sumbernya, maupun yang berasal dari pinjaman luar negeri, semuanya tentulah menjadi beban rakyat. Dalam kenyataanya memang badan eksekutiflah yang mengajukan rancangan pemasukan dan pengeluaran, namun parlemen tetap mempunyai kewenangan untuk merevisi atau mengubahnya. Setidak-tidaknya parlemen memberikan pengesahan terhadap rancangan anggaran yang diajukan oleh badan eksekutif. Kesemuanya itu merupakan fungsi keuangan (bugget) padan legislative (Sanit, 1985). 
Konsep perwakilan politik lokal terkait dengan sistem pemerintahan yang dipraktikkan satu negara. Konsep perwakilan politik lokal merupakan bagian yang tidak terpisah dari sistem demokrasi, artinya keterlibatan masyarakat secara langsung dan tidak langsung ikut menentukan urusan rumah tangga daerahnya. Mengingat luas daerah, jumlah penduduk, dan rumitnya aturan permainan demokrasi, maka hampir tidak mungkin setiap orang ikut terlibat dalam kegiatan penentuan, pengaturan, pengurusan, pengambilan keputusan, seperti yang berlaku pada negara atau kelompok-kelompok dalam masyarakat.

Namun sejalan dengan perkembangan praktik sistem pemerintahan, kajian lembaga legislatif tidak hanya pada lembaga legislatif di tingkat pusat. Kajian lembaga legislatif terus berkembang sejalan dengan perkembangan sistem otonomi daerah dan desetralisasi. Sejak saat itu lah kajian tentang lembaga legislatif lokal terus berkembang. Cikal bakal legislatif lokal bermula dari kesatuan negara kota (polis) di Yunani, "Canton" di Swiss, atau kesatuan masyarakat adat lainnya yang terdapat di kawasan nusantara. Dalam kesatuan masyarakat yang relatif kecil ini, dalam pengambilan keputusan tentang kebijakan atau tindakan yang hendak dijalankan, mereka putuskan lewat rapat atau lewat aturan main atau lewat pemungutan suara. Hal seperti itu menjadi aturan main atau "way of life" dari kesatuan masyarakat, dan tidak mengenal konsep perwakilan politik lokal. Setiap warga mewakili dirinya sendiri dan tidak menitipkan haknya kepada perwakilan.

Pemerintah lokal (daerah) sudah ada sebelum pemerintah pusat terbentuk. Pada zaman Yunani, suatu negara muncul mulai dari negara kota (city state atau polis), seperti Athena dan Sparta, yang dalam segi ukuran setingkat dengan satu pemerintahan daerah. Hal yang sama terdapat di Eropa pada abad ke XI dan XII pada saat mana muncul satuan-satuan wilayah di tingkat dasar yang scara alamiah membentuk suatu lembaga pemerintahan. Satuan komunitas tersebut merupakan entitas lembaga pemerintahan. Satuan komunitas tersebut merupakan entitas kolektif yang didasarkan pada hubungan saling mengenal dan saling membantu dalam ikatan geneologis maupun teritorial. Satuan komunitas ini membentuk kesatuan masyarakat hukum yang pada asalnya bersifat komunal (Nurcholis, 2005).

Pada awalnya satuan-satuan komunitas tersebut terbentuk atas kebutuhan anggotanya sendiri. Namun, untuk mempertahankan eksistensi dan keberlangsungan hidupnya, mereka membuat lembaga yang diperlukan yang mencakup lembaga politik, ekonomi, sosial, budaya, dan pertahanan-keamanan. Dengan demikian, lembaga terbentuk sangat beragam, tergantung pada pola tertentu berdasarkan adat istiadat komunitas yang bersangkutan. Dalam perkembangan berikutnya satuan-satuan komunitas tersebut dimasukkan ke dalam sistem administrasi negara dari suatu negara lalu berdaulat. Melalui keputusan politik, satuan komunitas tersebut lalu dibentuk menjadi unit organisasi formal dalam sistem administrasi negara pada tingkat lokal (Nurcholis, 2005). Perkembangan pembentukan negara-negara federal di Eropa, mereka muncul karena adanya kesepakatan antara pemerintah-pemerintah daerah yang ingin bersatu membentuk suatu negara bangsa (nation-state) (Sarundajang, 2004). 
Namun mengenai lahirnya satu negara masih banyak varian lainnya seperti konsep kontrak sosial (le contract social), penaklukan, dan juga lewat Proklamasi Kemerdekaan seperti pengalaman Amerika Serikat pada tahun 1787 dan pengalaman Indonesia sendiri pada tanggal 17 Agustus1945. Lahirnya pemerintahan daerah di Amerika Serikat dan Indonesia pada awalnya bersifat sporadis yang kemudian dikukuhkan dalam konstitusai negara yang bersangkutan.

Secara hipotesis, munculnya konsep perwakilan politik lokal di Indonesia ialah ketika pada saat itu ada pemerintahan lokal sebagai subsistem dari satu negara atau pemerintah pusat. Pemerintah lokal muncul di Indonesia ketika terjadi pembagian kekuasaan pemerintah yang dilakukan oleh quasi pemerintah pusat yaitu pimpinan tertinggi di Hindia Belanda, dalam hal ini Gubernur Jenderal dan semua pembantu-pembatunya. Hindia Belanda bukanlah negara melainkan daerah jajahan yang berinduk kepada raja atau ratu Belanda. Adapun eksistensi pemerintah daerah secara hukum masih "mewarisi" dari sistem pemerintahan Hindia Belanda, karena ketika Jepang menduduki Indonesia (1942-1945), dengan jelas masih memperlakukan sistem hukum dari Hindia Belanda, sepanjang tidak bertentangan dengan kepentingan Jepang (Marbun, 2005).

Republik Indonesia dalam UUD 1945 juga menetapkan dalam aturan peralihan pasal II: "segala badan negara dan peraturan yang ada masih langsung berlaku, selama belum diadakan yang baru menurut undag-undan dasar ini". Akan tetapi mengenai eksistensi pemerintah daerah sejak awal relah dirumuskan dalam Pasal 18 UUD, yang isinya, sebelum diamandemen tahun 2000: "pembagian daerah indonesia atas dasar besar dan kecil, dengan bentuk susudan pemerintahanya ditetapkan dengan undang-undang dengan memandang dan mengingat dasar permusyawaratan dalam sistem pemerintahan negara dan hakhak asal-usul dalam daerah-daerah yang bersifat istimewa".

Perwakilan politik lokal lahir sebagai konsekuensi desentralisasi untuk menjalankan fungsi-fungsi pemerintah daerah sesuai ketentuan perundangundangan yang mengaturnya. Pemerintahan daerah atau "local goverment" dapat berarti sebagai organ dan dapat juga sebagai fungsi. Sebagai fungsi "local goverment" diterjemahkan sebgai pemerintahan lokal. Sebgai organ, "local goverment" kerapkali disebut "local authority" yang mencakup council atau DPRD. "local government" dapat pula berarti sebagai otonom.

Bagi indonesia, baik masa penjajahan Hindia Belanda dan pada masa kemerdekaan sejak 1945, tafsir pemerintahan daerah atau "local goverment" sering berubah-ubah atau rancu. Hal ini terlihat umpamanya ketika pimpinan dewan daerah dijabat oleh kepala daerah (pada masa setelah desentralisasi 1903), juga sepanjang pengalaman DPRD pada periode 1945 dan 1959. Hal yang sama ditemui pula dalam definisi pemerintahan daerah yang dalam berbagai undangundang mempunyai definisi yang berbeda-beda.

Sebagai acuan yang berlaku internasional ada baiknya mengutarakan rumusan definisi "local goverment" yang dipublikasikan oleh PBB 1961, di mana "local goverment" didefinisikan sebagai : 
"....., a political subdivision of nation (or : in federal system, a state) which is constituded by law and has subtansial control of local affair, including the powers to impose taxes or to extract labor for aorescribed purpose. The governing body of such an entity is elected or other wise locally selected (UN, 1961)"

("Pemerintahan daerah (lokal) adalah subdivisi politik nasional yang diatur oleh hukum dan secara subtansial mempunyai kedala (kontrol)atas urusan-urusan local, termasuk kekuasaan untuk memungut pajak atau memecat pegawai untuk tujuan tertentu. Badan pemerintahan ini secara keseluruhan dipilih atau ditunjuk secara local")

Dari definisi PBB tantang "local goverment" terlihat dengan jelas bahwa pemerintahan daerah adalah subdivisi atau bagian dari negara. Dengan demikian pengaturan pelaksanaan pemerintahan pusat dalam saling kaitan struktural yang bersistem. Dengan demikian kehadiran perwakilan politk lokal adalah merupakan kelengkapan yang tidak terpisahkan dari pengelolaan pemerintahan daerah. Maka dengan demikian tuntutan pengadaan dan pemberdayaan perwakilan politik lokal adalah mempunyai landasan yang kuat, baik lewat ketentuan undang-undang maupun berlandaskan ketentuan konstitusi serta tuntutan demokrasi.

\section{Teori Tentang Lembaga Eksekutif}

Tugas badan eksekutif, menurut tafsiran tradisionil azas trias politica, hanya melaksanakan kebijakan-kebijakan yang telah ditetapkan oleh legislatif serta menyelenggarakan undang-undang yang telah dibuat oleh badan legislatif. Tetapi dalam pelaksanaannya badan eksekutif leluasa sekali ruang geraknya. Di zaman modern sekarang ini, eksekutif tidak hanya sekedar menjalankan undangundang tapi juga menjadi pengganti badan legislatif sebagai pembuat kebijakankebijakan utama pemerintahan (Budiardjo, 2000).

Seperti halnya dalam tradisi Amerika Serikat, presiden memiliki kekuasaan yang luas untuk mengatur masalah-maslah nasional dan menjaga jalannya pemerintahan federal. Presiden bisa mengeluarkan ketetapan-ketetapan, berbagai peraturan dan instruksi yang seluruhnya disebut perintah eksekutif (executive orders). Perintah ini tidak memerlukan persetujuan kongres namun memiliki kekuatan hukum yang mengikat atas perwakilan federal. Sebagai panglima tertinggi Angkatan Bersenjata Amerika Serikat, presiden juga dapat menugaskan Tentara Nasional (National Guard) untuk bertugas dipermerintahan federal. Dalam keadaan perang atau darurat nasional, Kongres dapat memberikan presiden kekuasaan yang lebih besar lagi untuk mengatur ekonomi nasional dan melindungi keamanan Amerika Serikat (Targonski, 2000).

Hal ini tidak berarti bahwa badan legislatif tidak punya peranan penting dalam penyelenggaraan pemerintahan Negara. Dalam Negara demokratis peran legislatif sangat penting dalam rangka menjaga jangan sampai eksekutif keluar dari garis-garis ketentuan yang telah ditetapkan.

Dalam rangka menjalankan roda pemerintahan, eksekutif diberikan kekuasaan dalam beberapa bidang (Budiardjo, 2000), antara lain : 
a. Diplomatik: eksekutif berhak menyelenggarakan hubungan diplomatik dengan Negara-negara lain.

b. Administratif: berhak melaksanakan undang-undang serta peraturanperaturan lain dan menjalankan administrasi Negara.

c. Militer: mengatur angkatan bersenjata, menyelenggarakan perang dan pertahanan Negara.

d. Yudikatif: memberi grasi, Amnesti dan sebagainya.

e. Legislatif: merencanakan rancangan undang-undang dan membimbingnya dalam badan perwakilan rakyat sampai menjadi undang-undang.

\section{Teori Elit dan Aktor Politik Lokal}

Teori elit dan aktor politik lokal menjadi sangat penting ketika meneliti tentang konflik politik yang sedang terjadi. Dengan tujuan teori ini dapat mengarahkan dan memperjelas siapa-siapa saja aktor politik dalam konflik antara eksekutif dan legislatif dalam proses penetapan APBD DKI Jakarta 2015. Asumsi teori elite mengatakan bahwa dalam setiap masyarakat terbagi dalam dua kategori.

1) Sekelompok kecil manusia yang memiliki kemampuan dan karenanya menduduki posisi untuk memerintah, dan mereka disebut : (a.) Elite yang berkuasa dan (b.) Elite yang tidak berkuasa. 2). Sejumlah besar massa yang ditakdirkan untuk diperintah. elite yang berkuasa jumlahnya relatif sedikit, mereka memiliki kemampuan dan kelebihan untuk memanfaatkan kekuasaan, mereka memegang semua fungsi politik, memonopoli kekuasaan sehingga dengan mudah memanfaatkannya untuk tujuan tujuan yang baik, misalnya kesejahteraan masyarakat, peningkatan pendidikan, perluasaan kesempatan kerja, peningkatan derajat kesehatan rakyat dan lain-lain, tetapi, kekuasaanya itu bisa digunakan untuk tujuan-tujuan yang tidak baik, misalnya : memperkaya diri sendiri, memperkuat posisi oligarki, memasukkan klan dan keluarganya dalam pemerintahan, menggalang kekuatan untuk memberangus oposisi dan lain-lain (Varma: 2001).

Di samping itu, terdapat elite yang tidak berkuasa, mereka menjadi lapis kedua dalam strata kekuasaan elite, lapisan elite ini akan menjadi pengganti elite diatasnya jika sewaktu-waktu elite pemegang kekuasaan kehilangan kemampuan untuk mengendalikan pemerintahaan, elite ini juga menjadi elite tandingan apabila elite yang berkuasa tidak mampu menjalankan tugas mengenda likan kekuasaan. Dalam perubahan sosial kalangan elite adalah sekelompok orang yang memiliki peranan penting, merekalah sebenarnya yang memberi acuan dan memberi arah terhadap perkembangan dan dinamika masyarakat.

Seperti yang diulas sebelumnya dalam realitasnya elite tidak tunggal (misalnya hanya politisi), ia berasal dari berbagai jenis dan macam elite. Masingmasing dari mereka dalam geraknya membawa interest, teknik, cara dan values sendiri-sendiri, menurut Rusadi Kantaprawira values itu disebut "nilai antara". Karena memiliki "nilai antara", masing-masing elite memiliki peranan yang berbeda-beda dalam perubahan sosial. Dinamika masyarakat suatu negara akan mengikuti perjalanan elite yang dominan, mereka mengarahkan perubahan 
masyarakat sesuai dengan kepentingan "nilai antara" atau arah capaian yang diinginkannya (Kantaprawira, 2004).

Putnam menganalisa peran dan pengaruh elite dari perspektif posisi, reputasi, dan pembuatan keputusan. Perbedaan ketiga perspektif antara lain sebagai berikut : Analisa posisi mengandaikan bahwa : (1) Orang yang berkuasa diantara sekelompok elite adalah orang yang menduduki posisi puncak dari organisasi formal tersebut; (2) Kekuasaan berkorelasi sepenuhnya dengan posisi kelembagaan; (3) Analisa posisi merupakan teknik analisa yang mudah dan paling umum dipergunakan untuk mengetahui siapakah sebenarnya orang yang berkuasa di lembaga tersebut; (4) Asumsi analisis ini beranggapan sudah diketahui lembaga-lembaga mana yang secara politis penting dan lembaga-lembaga mana yang mempunyai pengaruh semu; (5) Analisa posisi hanya efektif diterapkan dalam kondisi masyarakat/organisasi yang memiliki distribusi kekuasaan yang timpang, sementara dalam masyarakat dan organisasi yang distribusi kekuasaan merata analisis ini tidak efektif (Haryanto, 2005).

Singkatnya analisa ini berasumsi bahwa "siapa menduduki posisi puncak di suatu organisasi, orang itulah yang memiliki peran utama dan mempunyai pengaruh besar dalam gerak organisasi”. Analisa reputasi berasumsi bahwa: (1) Individu yang oleh sesama warga dianggap memiliki pengaruh, memang yang bersangkutan benar-benar memiliki pengaruh; (2) Individu yang oleh orang dianggap memiliki kekuasaan, memang yang bersangkutan benar-benar memiliki kekuasaan; (3) Analisa reputasi dilakukan dengan tidak mendasarkan pada lembaga-lembaga formal tetapi mendasarkan kepada reputasi kekuasaan secara informal yang dimiliki elite. Analisa pembuatan keputusan menekankan bahwa: (1) Untuk mengetahui siapa yang berkuasa diantara para elite dengan cara mempelajari proses pembuatan keputusan, perhatian utama dari analisa ini adalah siapa yang banyak berinisiatif dan memberi kontribusi terhadap pembuatan keputusan organisasi; (2) Dari proses ini juga diketahui siapa saja yang menjadi penentang dari proses pembuatan keputusan tersebut; (3) Analisa ini menurut sementara kalangan lebih efektif dibanding analisa posisi dan reputasi (Haryanto, 2005).

Berdasar analisa elite Putnan dan Suzanne Keller seperti diurai diatas yang dimaksud dengan elite penentu, alternatifnya adalah : (1). Orang yang menduduki posisi puncak dalam suatu organisasi; (2). Orang yang memiliki pengaruh dan reputasi besar dalam organisasi dibanding orang lain; (3). Orang yang memiliki kontribusi besar dalam pengambilan keputusan dalam organisasi. Namun jika ditemukan dalam suatu organisasi seorang individu tidak dalam posisi puncak namun reputasi dan kemampuan mengambil keputusan lebih besar dibanding orang lain termasuk orang yang sebenarnya menduduki posisi puncak maka orang ini disebut orang kuat (strongmen), sementara yang menduduki posisi tetapi kekuasaannya dibawah bayang-bayang orang kuat disebut elite boneka (toy of elite). Orang kuat di formulasikan secara sederhana sebagai berikut :

\section{Orang kuat $=$ Posisi $<$ Reputasi + Kontribusi Pengambilan Keputusan}


Penjelasannya : (1). Orang kuat adalah orang yang tidak dalam posisi puncak dalam suatu organisasi namun reputasi dan kontribusi pengambilan keputusan lebih besar dibandingkan orang lain termasuk orang yang menduduki posisi puncak; (2), jika berlangsung di partai, orang kuat partai adalah orang yang tidak menduduki posisi sebagai ketua umum namun reputasi dan kontribusi pengambilan keputusan lebih besar dibanding ketua umumnya sendiri dan orang orang dilingkaran kekuasaan partai; (3). Jika berlangsung di politik lokal, orang kuat lokal (local strongmen) adalah orang yang tidak dalam posisi pemerintah namun kapasitas dan kemampuan pengambilan keputusan di berbagai kebijakan lokal seperti distribusi dan alokasi sumberdaya daerah lebih menentukan dibanding state aparatus ditingkat lokal, karena itu orang ini di aras lokal bertindak sebagai bos lokal atau shadow government. Dengan demikian munculnya orang kuat bisa berlangsung dimana saja, kapan saja dan di komunitas apa saja, termasuk di partai politik dan di masyarakat seperti uraian tentang studi elite lokal (local strongmen,bossism) berikut ini.

Ada dua kerangka teoritik yang sering digunakan untuk menjelaskan fenomena kemunculan local strongmen dalam istilah Migdal atau Bossism menurut Sidel. Menurut Migdal, setiap kelompok dalam masyarakat mempunyai pemimpin, dimana pemimpin itu relatif otonom dari negara. Dan setiap masyarakat memiliki social capacity yang memungkinkan mereka menerapkan aturan main mereka sendiri tanpa diintervensi oleh negara.Ketika kapasitas negara untuk mengontrol melemah (weak state) maka para strongmen menapak kekuasaannnya dalam level lokal. Migdal (2001), menyebutkan strategi triangle of accommodation sebagai strategi strongmen untuk bertahan.Dengan demikian, Kehadiran strongmen merupakan refleksi dari kuatnya masyarakat (Migdal 2001).

Lebih jauh Migdal mengemukakan bahwa local strongmen bisa sukses karena pengaruh mereka dan bukan aturan resmi yang dibuat: "why local strongmen have, through their success at social control often effectively captured parts of third world states". Mereka sukses dalam menguasai posisi-posisi penting dan memastikan alokasi sumber daya karena pengaruh mereka (own rules), dan bukan karena aturan yang secara resmi dibuat. Ada tiga argumen yang menjelaskan fenomena keberhasilan orang kuat local, yaitu : (Migdal, 2001).

a. Local strongmen telah mengembangkan 'weblike societes' melalui organisasi otonom yang dimiliki, dalam kondisi masyarakat yang terfragmentasi secara sosial;

b. Local strongmen melakukan kontrol sosial melalui distribusi komponen yang disebut 'strategies of survival' dari masyarakat lokal. Ini menghasilkan pola personalism, clientalism, dan relasi patron-client.

c. Local strongmen menguasai state agency dan sumber daya, sehingga agenda kebijakan merupakan hasil kompromi dengan kepentingan local strongmen. Local strongmen melakukan kontrol dan limitasi atas otonomi dan kapasitas negara, dan berhasil melemahkan negara dalam proses pencapaian tujuan perubahan sosial.

Orang kuat lokal melanggengkan kekuasaannya dengan cara-cara berkolaborasi dengan negara dan partai politik pemerintah, melakukan stationary 
bandit dan rowing bandit (kriminalitas). Local strongmen dapat bertahan asalkan ia berkolaborasi dengan negara dan partai politik pemerintah, berdasar hal tersebut maka terbentuklah "triangle of accomodation". Ironisnya, triangle ini mengijinkan sumber daya negara untuk memperkuat local strongmen dan organisasinya yang mengatur the game conflict. Keberlangsungan local strongmen juga tergantung pada kekuatan negara untuk mengatur kontrol mereka, mereka belajar mengakomodasi pemimpin yang populis untuk menangkap organisasi negara pada level yang lebih rendah (Migdal, 2001).

Berbeda dengan Sidal, berdasarkan studinya tentang elite lokal di Philipina, Sidel mengatakan bahwa konsep bossism merujuk: "predatory power brokers who achieve monopolistic control over both coercive and economic resources within give territorial jurisdictions or bailiwicks". Faktor yang menjamin keberlangsungan bossism di Philipina : (a) Struktur institusi negara; (b) Konsentrasi modal swasta di daerah sebagai bagian kebijakan negara; (c) Warisan Amerika berupa sistem pemilu Philipina; (d) Keikutsertaan aparat negara pada masa-masa awal capitalist development. Sidel berkesimpulan bahwa eksistensi dan keberlangsungan bos merupakan refleksi kekuatan Negara. Penggunaan coercive violence merupakan strategi yang digunakan para bos di Philipina untuk bertahan (Sidel, 1999).

Sidel pada tulisan berikutnya melanjutkan analisis tentang local strongmen dengan membandingkan kasus di negara Philipina, Thailand dan Indonesia. Khusus di Indonesia local strongmen diulas Sidel dengan setting fenomena pemilihan kepala daerah yang melibatkan : politik uang, premanisme, keterlibatan kelompok ekonomi kuat dan keterlibatan kelompok preman. Menurut Sidel pada jaman orde baru local strongmen di ilustrasikan sebagai berikut: (a) Konteks pergeseran dari sentralisme kekuasaan ke desentralisasi kekuasaan, berpindahnya kekuasaan "dari satu Suharto ke banyak Suharto?"; (b) Orde baru yang monolitik telah melimitasi munculnya Local Strongmen, karena semua saluran ke arah kekuasaan ada di satu pintu rejim Orde Baru (Suharto, Golkar, dan AD); (c) Adalah karena organisasi kuasa negara dengan pola sentralistis yang membuat local strongmen tidak muncul, dan bukan masyarakat jika pola organisasi kuasa muncul, maka local strongmen akan tumbuh. Singkatnya sangat terpusat dan watak dasar otoriter negara zaman Soeharto tidak memungkinkan bagi para "bos lokal" untuk bermunculan, bertahan hidup, dan tumbuh subur di Indonesia hingga menjelang pergantian abad. (d) Tetapi orde baru juga memfasilitasi munculnya elite lokal antara lain pensiunan tentara yang menduduki pos-pos lokal; elite lokal yang mendapatkan kewenangan kontrol dari negara atas sumber daya ekonomi tertentu (state lands allocation); anggota DPRD lokal (Sidel, 1999).

Dalam konteks sistem otonomi daerah, aktor-aktor politik dan konfigurasi kekuasaannya lebih beragam dan terbentang secara horizontal. Terlebih dikaitkan dengan kontelasi politik di DKI Jakarta, yang notabene daerah khusus ibukota, tentu aktor-aktor politik yang bermain sangat beragam. Dalam konteks penelitian ini, aktor politik di DKI Jakarta serta konfigurasi kekuasaan di DKI dapat dibedakan dalam dua ranah, yakni formal dan informal, dan dalam konteks 
tertentu terdapat pembilahan secara jelas siapa-siapa saja elit/aktor politik berpengaruh di DKI Jakarta yang akan ditelaah lebih jauh dalam penelitian ini.

\section{Teori Kewenangan dan Kekuasaan}

Secara konseptual, istilah kewenangan (authority) dan kekuasaan (power) memiliki keterikatan satu dengan lainnya. Pada hakekatnya kewenangan merupakan kekuasaan, akan tetapi kekuasaan belum tentu berupa kewenangan. Pendefinisian tersebut merujuk pada pendapat Robert Bierstedt dalam bukunya "An Analysis of Social Power", yang mengatakan bahwa kewenangan merupakan kekuasaan yang dilembagakan (institutionalized power). Definisi kewenangan tersebut juga sejalan dengan pendapat yang dikemukakan oleh Harold D. Laswell dan Abraham Kaplan dalam "Power and Society", yang menyatakan bahwa wewenang merupakan kekuasaan formal, artinya yang berhak untuk memberikan perintah serta membuat dan merumuskan peraturan-peraturan adalah mereka yang memiliki kewenangan (Budiardjo, 2008).

Dilihat dari perspektif sosiologi, kewenangan adalah hak yang dimiliki seseorang atau sekelompok orang. Dalam hal ini penekanannya adalah pada hak, dan bukan pada kekuasaan. Dengan kata lain kekuasaan tanpa wewenang, merupakan kekuasaan yang tidak sah. Karena kekuasaan harus mendapatkan pengakuan dan pengesahan dari masyarakat agar menjadi wewenang. Agar seseorang ataupun sekelompok orang yang memiliki kekuasaan tersebut dapat mempunyai sebuah kewenangan atas kekuasaannya itu, maka pihak yang bersangkutan tersebut dapat memperolehnya dari berbagai sumber kewenangan yang ada. Dengan melalui berbagai sumber-sumber kewenangan tersebut mereka dapat memperoleh keabsahan ataupun hak atas kekuasaan yang dimilikinya tersebut (Soekanto, 2002).

Dalam kaitannya dengan sumber kewenangan, Charles Andrain (Haryanto, 2005) membagi sumber-sumber kewenangan dalam 5 (lima) sumber, yaitu :

1. Kewenangan dapat diperoleh dari sumber-sumber primordial, khususnya dari sifat-sifat keturunan. Sebagai contoh : di beberapa masyarakat tertentu, hanya orang-orang yang menjadi anggota keluarga kerajaan atau keturunan raja yang mempunyai hak untuk berkuasa.

2. Kewenangan juga dapat diperoleh dari sumber-sumber yang dianggap suci, yakni dari Tuhan. Sumber kewenangan ini menunjukkan bahwa hak untuk memerintah dinilai bersifat sakral. Sebagai contoh : Raja-raja pada masa lalu merupakan sebagai individu yang memiliki kewenangan yang bersumber dari hal-hal yang dianggap suci.

3. Kewenangan dapat diperoleh dari sumber-sumber pribadi. Sumber kewenangan ini menunjukkan bahwa hak untuk memerintah berasal dari kualitas pribadi pemegang kekuasaan. Hal tersebut dapat ditunjukkan dimilikinya charisma atau daya tarik pada diri seseorang yang memiliki kekuasaan.

4. Kewenangan dapat diperoleh dari sumber-sumber instrumental. Dalam 
hal ini, sumber kewenangan ditunjukkan dari hak untuk memerintah berasal dari instrument yang dimilikinya, seperti keahlian, ketrampilan ataupun kekayaannya. Sebagai contoh : kewenangan yang dimiliki seseorang berdasarkan atas keahlian dibidang terntentu dan kekayaan berlimpah ruah yang dimilikinya.

5. Kewenangan dapat diperoleh dari sumber-sumber yang bersifat legal atau konstitusional. masyarakat atau Negara kosntitusional biasanya mensyaratkan bahwa seseorang mempunyai hak untuk memerintah kalau yang bersangkutan secara prosedural memenuhi peraturan perundangan yang berlaku. Oleh karena itu di masyarakat atau Negara konstitusional, landasan yang bersifat legal bagi dimilikinya wewenang menjadi syarat yang penting.

Adapun Max Weber di dalam bukunya yang berjudul "The Theory of Social and Economic Organization", membedakan wewenang atau kewenangan dalam 3 (tiga) bentuk yaitu wewenang kharismatis, wewenang rasional (legal) dan wewenang tradisional. Pembedaan tersebut didasarkan pada hubungan antara tindakan dengan dasar hukum yang berlaku (Weber, 1947). Bentuk yang pertama adalah wewenang kharismatis, merupakan wewenang yang didasarkan pada kharisma, yaitu suatu kemampuan khusus (kesaktian dan kekuatan mistik, atau religius) yang ada pada diri seseorang. Kemampuan khusus tadi melekat pada diri orang tesebut karena anugerah dari Tuhan. Biasanya kewenangan yang bersumberkan pada kualitas pribadi ini tidak dapat diwariskan. Sebagai contoh seseorang dinyatakan mempunyai kewenangan untuk berkuasa karena ia mempunyai kemampuan supranatural ataupun mukjizat (para Nabi/Rasul) yang tidak dimiliki oleh anggota masyarakat pada umumnya.

Kedua adalah wewenang rasional (legal), merupakan wewenang yang disandarkan pada sistem hukum yang berlaku dalam masyarakat. Sistem hukum disini dipahamkan sebagai kaidah-kaidah (Undang-Undang Dasar, UndangUndang, dan lain-lain) yang telah diakui serta ditaati oleh masyarakat, dan bahkan yang telah diperkuat oleh Negara. Dengan pengertian lain, dalam hal ini yang ditekankan bukan individunya akan tetapi aturan-aturan yang mendasari tingkah lakunya. Contoh: seseorang diangkat sebagai pemimpin karena ia selain mempunyai kemampuan untuk menjalankan kekuasaan, dia juga telah memenuhi persyaratan yang ditetapkan secara legal sebagai suatu peraturan (Weber, 1947).

Terakhir adalah wewenang Tradisional, merupakan wewenang yang dimiliki oleh seseorang atau sekelompok orang atas dasar tradisi kepercayaan oleh masyarakat secara turun temurun. Atau pengertian lainnya, wewenang yang dimiliki oleh seseorang atau sekelompok orang tadi bukan lantaran mereka memiliki kemampuan-kemampuan khusus seperti pada wewenang kharismatis namun karena mereka memiliki kekuasaan yang telah melembaga dan menjiwai masyarakat (kerajaan). sebagai ilustrasi, berdasarkan tradisi masyarakat dahulu hingga saat ini seorang anak raja/putra mahkota mempunyai hak (kekuasaan dan kewenangan) untuk menggantikan kedudukan kedua orang tuanya tanpa melalui proses aturan-aturan yang berlaku seperti pada wewenang rasional-legal. 
Dalam kajian ilmu sosial dan ilmu politik konsep kekuasaan merupakan konsep yang sangat krusial, bahkan pernah politik dianggap identik dengan kekuasaan, terutama kekuasaan untuk mempertahankan sebuah kedudukan atau kepentingan. Harold D. Laswell dan Abraham Kaplan, mendefinisikan kekuasaan sebagai suatu hubungan di mana seseorang atau sekelompok orang dapat menentukan tindakan seseorang atau kelompok lain kea rah tujuan dari pihak pertama (Power is a relationship in which one person or group is able to determine the action of another in the direction of the former's own ends) (Budiardjo, 2008).

Sementara Weber mengatakan, kekuasaan adalah kesempatan seseorang atau sekelompok orang untuk menyadarkan masyarakat akan kemauankemauannya sendiri, dengan sekaligus menerapkannya terhadap tindakantindakan perlawanan dari orang-orang atau golongan-golongan tertentu (Weber, 1946). Definisi kekuasaan yang dikemukakan oleh Weber senada dengan perspektif Talcott Parsons yang mengatakan bahwa :

"Power then is generalized capacity to secure the performance of binding obligation by units in a system of collective organization when the obligation are legitimized with reference to their bearing on collective goals, and where in case of recalcitrancy there is a presumption of enforcement by negative situational sanction-whatever the agency of the enforcement. (Kekuasaan adalah kemampuan untuk menjamin terlaksanananya kewajiban-kewajiban yang mengikat, oleh kesatuan- kesatuan dalam suatu sistem organisasi kolektif. Kewajiban adalah sah jika menyangkut tujuan-tujuan kolektif. Jika ada perlawanan, maka pemaksaan melalui sanksi-sanksi negatif dianggap wajar, terlepas dari siapa yang melaksanakan pemaksaan itu) (Parsons, 1957).

Dari kedua perspektif mengenai kekuasaan di atas dapat dijelaskan bahwa baik Weber maupun Parsons melihat segi positif dari kekuasaan itu sendiri terutama jika dikorelasikan dengan kewenangan. Sebagai pembeda diantara keduanya, kewenangan diartikulasikan sebagai kekuasaan yang memiliki keabsahan, sementara kekuasaan tidak selalu memiliki keabsahan. Selain itu perbedaan antara kekuasaan dan kewenangan, kekuasaan ialah kemampuan untuk mempengaruhi pihak lain. Sedangkan kewenangan merupakan kekuasaan yang ada pada seseorang atau sekelompok orang, yang mempunyai dukungan atau mendapat pengakuan dari masyarakat.

Pada konteks di atas pengertian kewenangan timbul pada waktu masyarakat mulai mengatur pembagian kekuasaan dan menentukan penggunaannya. Tetapi ironisnya, tidak ada suatu masyarakatpun di dalam sejarah manusia, yang berhasil dengan sadar mengatur setiap macam kekuasaan yang ada di dalam masyarakat itu menjadi wewenang (Soekanto, 2002). Hal tersebutlah yang sampai saat ini kerap kali terjadi tumpang tindih atau benturan antar kewenangan di dalam kehidupan bermasyarakat maupun bernegara. 


\section{METODE PENELITIAN \\ Desain Penelitian}

Sesuai dengan tujuan yang ingin dicapai, maka penelitian ini menggunakan metode penelitian kualitatif. Metode kualitatif sendiri berasal dari tradisi penelitian phenomenology, sebuah metode yang dipakai untuk menjelaskan fenomena atau gejala sosial (Miles \& Huberman, 1984). Menurut Kirk dan Miller, penelitian kualitatif adalah tradisi tertentu dalam pengetahuan sosial yang secara fundamental yang bergantung pada pengamatan manusia dalam kawasannya sendiri dan berhubungan dengan orang-orang tersebut dalam bahasanya dan dalam peristilahannya (Moleong, 2003). Metode ini dipakai mengingat penelitian ini bermaksud untuk memahami dan menganalisa Konflik Politik Gubernur Dan DPRD DKI Jakarta Dalam Penyelenggaraan Program Jakarta Sehat Tahun 2013.

Dalam hal ini, Bogdan dan Taylor (Moloeng, 2007) menjelaskan bahwa metode penelitian kualitatif merupakan suatu prosedur penelitian yang menghasilkan data berupa naskah wawancara orang-orang yang diamati, catatan lapangan, foto, jejaring, tabel, gambar dan lain sebagainya untuk memperoleh kejelasan makna dari setiap pola perilaku yang ditunjukkan oleh subyek penelitian. Sedangkan jenis penelitian yang digunakan berupa studi kasus, yaitu suatu pendekatan yang mengeksplorasi suatu konsep atau fenomena tertentu secara intensif, mendalam, mendetail dan komprehensif, dimana peneliti sebagai instrumen kunci (researcher as key instrument) mengumpulkan sendiri data melalui dokumentasi, observasi perilaku dan wawancara dengan para partisipan dengan menggunakan data set penelitian sebagai panduan dalam melakukan penelitian.

Secara teoritis, penggunaan metode kualitatif juga memiliki kelebihan tersendiri. Dalam hal ini Moleong memaparkan beberapa kelebihan dari metode kualitatif. Pertama, Metode ini lebih mudah disesuaikan bila berhadapan dengan kenyataan ganda. Kedua, metode ini menyajikan secara langsung hubungan antara peneliti dan responden. Ketiga, metode ini lebih peka dan dapat menyesuaikan diri dengan banyak penajaman pengaruh bersama dan terhadap pola-pola nilai yang dihadapi (Moloeng, 2007).

Dalam teknik penulisan, penelitian ini bersifat deskriptif, karena akan menggambarkan secara terinci fenomena sosial tertentu. Penelitian deskriptif hanya bertujuan membuat deskripsi suatu fenomena atau deskripsi suatu fenomena secara terpisah-pisah. Miles dan Huberman mengungkapkan bahwa metode deskriptif bertujuan melukiskan fakta atau karakteristik populasi tertentu secara faktual dan cermat. Dengan demikian, penelitian yang bersifat deskriptif bertujuan menemukan fakta dengan interpretasi yang tepat. Studi yang dilakukan formulatif dan eksploratif untuk mengenal fenomena-fenomena yang ada.

Penulis menggunakan metode kualitatif dikarenakan dalam pembahasan konflik politik antara Gubernur dan DPRD DKI Jakarta dalam proses penetapan APBD 2015, penulis ingin mendapatkan gambaran secara menyeluruh, di mana gambaran konflik dapat dipahami dengan cara meneliti kedua belah pihak yang berkonflik. Sehingga dalam penelitian ini penulis tidak mencari pengaruh 
keterkaitan variable sebagaimana ada batasan-batasan masalah melainkan menganalisis berdasarkan situasi di lapangan (place, actor, dan activity) yang terjadi.

Alasan lain menggunakan desain penelitian ini adalah untuk memperoleh pemahaman yang lebih mendalam tentang mengapa terjadi konflik antara Gubernur dan DPRD DKI Jakarta dalam proses penetapan APBD 2015. Penyebab yang dimaksud sebagaimana dijelaskan oleh Paul M. Collier (Collier, 2003) bahwa konflik politik terjadi disebabkan oleh dua faktor utama, yakni perbedaan kepentingan, dan perebutan sumber daya (resources) yang langka atau sangat terbatas, seperti jabatan dan kekuasaan politik. Tahap selanjutnya adalah melihat pola penyelesaian konflik politik yang terjadi, sebagaimana merujuk pada konsep Simon Fisher (Fisher dan Kartikasari, 2001), yakni yakni negosiasi, mediasi, dan arbitrase.

Dengan menggunakan desain penelitian kualitatif, penulis dapat menentukan langkah-langkah penelitian, yang dimulai dari menentukan rumusan masalah penelitian. Langkah selanjutnya adalah menentukan sampel penelitian yang relevan, karena dalam penelitian kualitatif, validitas dan akurasi data tidak didasarkan pada banyaknya sampel, namun didasarkan pada kualitas dan kompetensi sampel. Langkah selanjutnya adalah proses pengumpulan data di lapangan, yang kemudian dilanjutkan dengan proses reduksi data. Langkah terakhir dalam penelitian ini adalah analisa data dan penulisan kesimpulan penelitian.

\section{Pendekatan Penelitian}

Penelitian ini dilakukan dengan pendekatan studi kasus (case study). Menurut Johnson pendekatan studi kasus menyediakan cara untuk mempelajari sebuah sistem yang terbatas sepanjang waktu melalui detail-detail dan koleksi data yang mendalam serta melibatkan beberapa sumber informasi yang kaya dengan konteks. Umumnya penelitian yang menggunakan pendekatan studi kasus merupakan strategi yang tepat bila "how" atau "why" merupakan pokok pertanyaan penelitiannya, atau hanya sedikit peluang yang dimiliki oleh peneliti untuk dapat mengontrol peristiwa-peristiwa yang akan diselidiki, dan bilamana fokus penelitiannya terletak pada fenomena kontemporer (masa kini) di dalam konteks kehidupan nyata. Didasarkan pada pandangan inilah penulis melakukan penelitian tentang kinarja DPRD, dengan mengambil studi kasus penelitian tentang Konflik Politik Gubernur Dan DPRD DKI Jakarta Dalam Proses Penetapan APBD 2015.

Menurut Stake dalam Denzin, pendekatan studi kasus (case study) memberikan perhatian kepada pertanyaan mengenai tentang apa yang dipelajari secara khsusus terkait dengan suatu kasus yang akan diteliti. Sedangkan Harrison White mengelompokkan penelitian studi kasus ilmu-ilmu sosial didasarkan kepada tujuannya, apakah studi kasus bertujuan untuk mengidentifikasi, atau menjelaskan dan atau sebagai kontrol. Lebih lanjut Stake mengatakan bahwa studi kasus dibagi menjadi tiga bagian, yaitu (Moloeng, 2007) :

1. Intrinsic case study, dalam hal ini peneliti menginginkan adanya 
sebuah pemahaman yang lebih baik atas suatu kasus tertentu.

2. Instrumental case study, dimana ketika suatu kasus diuji tertutama digunakan untuk memberikan gambaran atas suatu isu dan atau menggambarkan kembali sebuah generalisasi. Dikarenakan peneliti memiliki beberapa kepentingan, baik secara umum maupun khusus, maka antara intrinsic case study dan instrumental case study tidak memiliki batasan atau pemisahan dengan jelas.

3. Terakhir collective case study, adalah ketika peneliti mempelajari sejumlah kasus yang digunakan untuk meneliti fenomena, populasi, atau kondisi umum.

Dengan mengacu pada tiga jenis pendekatan studi kasus tersebut, maka penelitian tentang Konflik Politik Gubernur Dan DPRD DKI Jakarta Dalam Proses Penetapan APBD 2015 lebih cenderung terkategori dalam model intrinsic case study dan instrumental case study. Hal ini mengingat, peneliti menginginkan adanya sebuah pemahaman yang lebih baik atas suatu kasus tertentu, serta bermaksud untuk memberikan gambaran atas suatu isu dan atau menggambarkan kembali sebuah generalisasi.

\section{Objek Penelitian}

Dalam penelitian kualitatif, istilah populasi merupakan situasi sosial (social situation), dan aktivitas (activity). Dengan situasi sosial atau objek penelitian sedemikian, peneliti dapat mengamati secara mendalam aktivitas (activity). Orang-orang (actors) yang berada disuatu tempat (place) tertentu (Sugiyono, 2010). Oleh karena itu, maka objek penelitian ini adalah Konflik Politik Gubernur Dan DPRD DKI Jakarta Dalam Proses Penetapan APBD 2015. Di mana konflik tersebut melibatkan para aktor kekuasaan antara Gubernur dan DPRD DKI Jakarta. Penelitian ini dilakukan, untuk memperoleh pemahaman yang lebih mendalam tentang mengapa terjadi Konflik Politik Gubernur Dan DPRD DKI Jakarta Dalam Proses Penetapan APBD 2015.

\section{Sumber dan Teknik Pengumpulan Data}

Dalam penelitian kualitatif metode pengumpulan data dengan melakukan peran serta wawancara. Selain itu juga dapat dilakukan dengan analisis dokumen (metode historis) yang bersifat fundamental dan dapat digunakan secara bersamasama. Metode tersebut dirasa lebih baik karena memungkinkan peneliti memadukan simbol dan interaksi, selain itu peneliti bisa mengambil peran yang diamati serta memasuki dunia obyek penelitian. Peneliti juga bisa mengaitkan simbol-simbol dengan dunia sosial, merekam berbagai situasi perilaku serta mengungkapkan perubahan proses dan membuat konsep-konsep atas perilaku obyek dengan lebih terarah (Mulyana, 2002).

Oleh karenanya, sumber data dalam penelitian ini akan diperoleh dari sumber infomasi primer dan sumber data sekunder. Data sekunder diperoleh dari berbagai dokumen terkait penyelenggaraan program Jakarta Sehat yang diselenggarakan gubernur dan wakil gubernur DKI Jakarta tahun 2013. Sedangkan data primer diperloleh secara langsung melalui interview terhadap 
objek yang diteliti. Untuk mempermudah proses pengumpulan tersebut, peneliti mencatat dan merekam informasi serta mendokumentasikannya, sehingga memudahkan peneliti untuk menganalisis dalam langkah penelitian pada saat melakukan analisis data.

Pengumpulan adalah keperluan proses pengadaan data untuk mendukung argumen-argumen dan asumsi-asumsi dalam membuktikan kebenaran penelitian. Pengumpulan data akan dilakukan dengan menggunakan purposeful sampling dimana informasi diperoleh dari orang-orang tertentu yang memungkinkan peneliti mempelajari isu sentral yang penting bagi tujuan penelitian (Patton, 1990). Sedangkan strategi pengumpulan data menggunakan stratified purposeful sampling untuk menggambarkan karakteristik kelompok-kelompok tertentu untuk diperbandingkan. Prosedur penelitian melibatkan empat jenis strategi (Creswell, 2010):

1. Observasi. Peneliti turun langsung ke lapangan untuk mengamati peristiwa aktivitas individu-individu di lokasi penelitian. Dalam pengamatan ini, peneliti merekam atau mencatat secara terstruktur maupun semi terstruktur aktivitas-aktivitas dalam lokasi penelitian. Peneliti juga dapat terlibat dalam peran-peran yang beragam, mulai dari sebagai non-partisipan hingga partisipan utuh.

2. Wawancara. Peneliti melakukan face-to-face interview (wawancara berhadap-hadapan) dengan partisipan, mewawancarai mereka dengan telepon, atau terlibat dalam wawancara dalam kelompok tertentu yang memberikan pertanyaan-pertanyaan tidak terstruktur (unstructured) dan bersifat terbuka (open-ended) dirancang untuk memunculkan pandangan dan opini dari para partisipan.

3. Dokumentasi. Pengumpulan dokumen kualitatif berupa dokumen publik (koran, makalah, laporan kantor) ataupun dokumen pribadi (buku harian, diary, surat, e-mail).

4. Materi Audio dan Visual. Data ini berupa foto, objek-objek, video tape, atau segala jenis suara/bunyi.

\section{Penentuan Informan}

Unit analisis penelitian adalah organisasi dengan unit observasinya, di mana individu-individu sebagai key informants. Penelitian kualitatif merupakan bagian dari kajian dan pembentukan teori yang berkaitan dengan aturan pemaknaan dan interpretasi. Makna bukan sesuatu atau substansi, tapi suatu aktivitas. Jadi teori ini menjelaskan bagaiamana masyarakat menjelaskan apa yang mereka teliti atau lakukan (Moloeng, 2007).

Informan dalam penelitian ini adalah subjek pelaku yang mengetahui, mengalami dan memahami akan masalah yang diteliti, tentang Konflik Politik Gubernur dan DPRD DKI Jakarta dalam proses penetapan APBD 2015. Informasi berbentuk data primer dan sekunder yang diperlukan meliputi kata-kata dan tindakan informan, termasuk dokumentasi yang terkait dengan masalah tersebut di atas. 
Adapun subjek pelaku yang mengalami dan memiliki pengetahuan serta kemampuan untuk memberikan informasi terhadap masalah Mengapa Konflik politik Gubernur dan legislatif Provinsi DKI Jakarta dalam proses penetapan APBD 2015, dapat dikategorikan sebagai berikut :

1. Pihak Pemerintah Provinsi.

a. Gubernur atau Wakil Gubernur;

b. Sekretaris Daerah Provinsi DKI Jakarta;

2. Pimpinan DPRD DKI Jakarta, Ketua Fraksi di DPRD DKI Jakarta.

3. Pengamat politik dan kebijakan publik.

Informan yang dipilih didasarkan pada karakteristik kesesuaian dengan data yang diperlukan yakni : Gubernur atau Wakil Gubernur, Kepala Dinas Kesehatan DKI Jakarta, dan anggota DPRD yang terlibat dalam proses penetapan APBD 2015. Informan tersebut, diperoleh tidak berdasarkan pada jumlah yang dibutuhkan, melainkan berdasarkan pertimbangan fungsi dan peran informan sesuai fokus masalah penelitian. Kategori subjek informan adalah mereka yang terlibat langsung dalam proses penetapan APBD 2015. Wawancara dilakukan berulang-ulang dan ada pula informan yang di wawancarai dalam batasan tertentu, yaitu kepala dinas kesehatan. Sedangkan yang menjadi indikator dalam pemilihan informan dalam penelitian adalah dengan melihat situasi sosial yang meliputi aspek: latar (setting), para pelaku (actor), peristiwa-peristiwa (event) dan proses (process).

\section{Reduksi Data}

Pada tahap ini penulis melakukan proses pengumpulan data mentah, dengan menggunakan alat-alat yang perlu seperti alat perekam, catatan lapangan serta observasi yang dilakukan penulis selama berada dilokasi penelitian. Pada tahapan ini penulis sekaligus melakukan proses penyeleksian, penyederhanaan, pemfokusan dan pengabstraksian data dari catatan lapangan dan transkrip hasil wawancara. Proses ini berlangsung selama penelitian dan penulis akan melakukannya dengan menggunakan singkatan, kategorisasi, memusatkan tema, menentukan batas-batas permasalahan. Reduksi data seperti ini menurut penulis sangat diperlukan sebagai analisis yang akan menyeleksi, mempertegas, membuat fokus dan membuang hal yang tidak penting serta mengatur sedemikian rupa sehingga menghasilkan sebuah kesimpulan.

Pada tahap selanjutnya, setelah memperoleh data hasil wawancara yang berupa rekaman, catatan lapangan, dan pengamatan lainnya. Penulis melakukan transkrip data untuk merubah data hasil wawancara dan catatan lapangan dalam bentuk tulisan yang lebih teratur dan sistematis. Setelah seluruh data dirubah dalam bentuk tertulis, penulis membaca seluruh data tersebut dan mencari hal-hal yang perlu dicatat untuk proses selanjutnya yakni pengkategorisasian agar data yang diperoleh lebih sederhana sesuai dengan kebutuhan penelitian. Sampai disini diperoleh kesimpulan sementara berdasarkan data yang telah ada. Pada tahap selanjutnya, penulis melakukan triangulasi yakni check and recheck antara satu sumber data dengan sumber data yang lainnya. Apakah ssumber data yang satu 
sesuai dengan data yang lainnya. Hal tersebut dilakukan untuk meningkatkan validitas data yang diperoleh.

\section{Analisis Data}

Dalam penelitian ini tidak digunakan populasi dan sampel tetapi unit analisis dan partisipan sebagai obyek maupun sumber data. Sebagai unit analisis pada penelitian ini adalah Konflik Politik Gubernur dan DPRD di Daerah Khusus Ibukota (DKI) Jakarta, dalam penyelenggaraan program Jakarta Sehat Tahun 2013.

Proses analisis data dimulai dengan menelaah seluruh data yang tersedia dari berbagai sumber, yaitu wawancara, pengamatan yang sudah ditulis dalam catatan lapangan, dokumen-dokumen, gambar, foto, dan lain- lain. Setelah dibaca, dipelajari dan ditelaah, langkah berikutnya adalah mereduksi data dengan melakukan abstraksi (membuat rangkuman inti, proses dan pernyataan-pernyataan yang perlu dijaga) yang disusun dalam satuan-satuan. Kemudian satuan-satuan tersebut dikategorisasikan sambil melakukan koding. Penafsiran data dilakukan dalam mengolah hasil sementara setelah pemeriksaaan keabsahan data selesai.

Pengambilan keputusan atau verifikasi merupakan kegiatan pada akhir Penelitian kualitatif. Dari awal, peneliti mencari makna dari data yang diperoleh, kemudian data tersebut disimpulkan. Makna yang dirumuskan oleh peneliti berasal dari data yang telah diuji kebenarannya. Dalam mencari makna, peneliti menggunakan pendekatan emik, yaitu penafsiran makna menurut key informan, dan pendekatan etik, yaitu penafsiran makna menurut peneliti. Kegiatan analisis data menggunakan model Miles dan Huberman (1994), seperti dalam gambar 1 di bawah ini ;

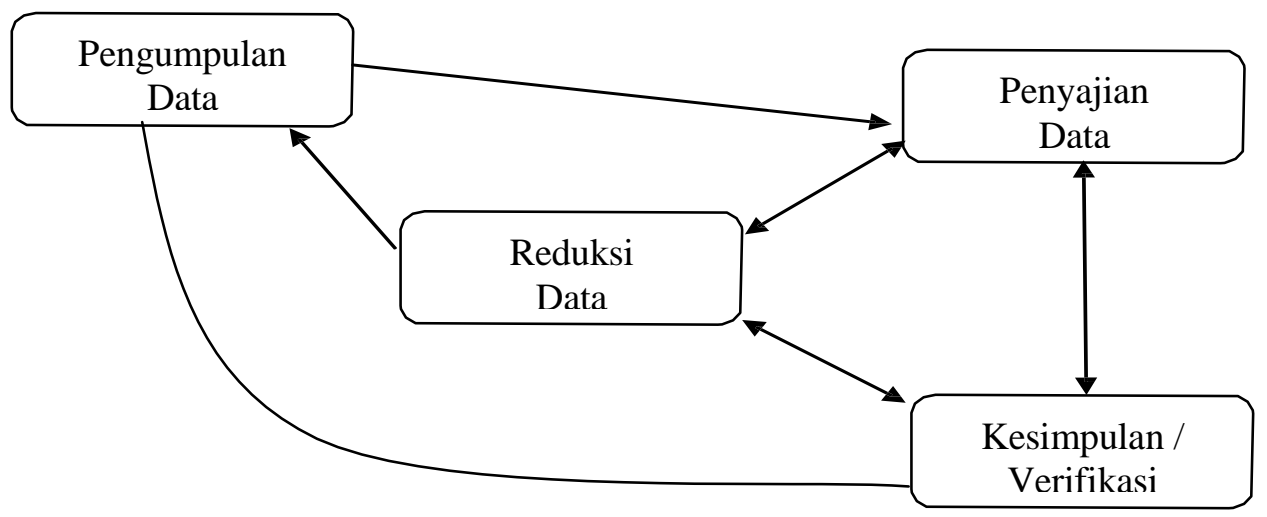

Gambar 1. Model Interaktif Miles dan Huberman

\section{Validitas dan Reliabilitas Data}

Dalam penelitian kualitatif, validitas merupakan upaya pemeriksaan terhadap akurasi hasil penelitian dengan menetapkan prosedur-prosedur tertentu. Menurut Yin (2005) peneliti kualitatif harus mendokumentasikan sebanyak 
mungkin langkah prosedur studi mereka dengan memaksimalkan empat aspek kualitas penelitiannya, yaitu:

1. Validitas konstruk; menetapkan ukuran operasional yang benar untuk konsep-konsep yang akan diteliti.

2. Validitas internal; menetapkan hubungan kausal, dimana kondisi-kondisi tertentu diperlihatkan guna mengarahkan kondisi-kondisi lain, sebagaimana dibedakan dari hubungan semu.

3. Validitas eksternal; menetapkan ranah dimana temuan suatu penelitian dapat divisualisasikan.

4. Reliabilitas; menunjukkan bahwa pelaksanaan suatu penelitian, seperti prosedur pengumpulan data dapat diinterpretasikan dengan hasil yang sama.

Pemeriksaan akurasi validitas data akan mempergunakan strategi triangulasi (triangulate) dimana berbagai bukti yang berasal dari sumber-sumber tersebut dipergunakan untuk membangun justifikasi tema-tema secara koheren. Tema-tema yang dibangun dari sejumlah sumber data atau perspektif dari partisipan akan menambah validitas penelitian. Sedangkan reliabilitas kualitatif mengindikasikan bahwa pendekatan yang digunakan peneliti konsisten jika diterapkan oleh peneliti-peneliti lain dan untuk proyek-proyek yang berbeda (Gibbs dalam Creswell, 2010).

\section{Penyebab dan Dampak Konflik \\ Kondisi Ekonomi dan Sosial Masyarakat DKI Jakarta Kondisi Ekonomi}

Daerah Khusus Ibukota Jakarta bukanlah sekedar sebagai pusat pemerintahan negara Republik Indonesia, juga berfungsi sebagai pusat perdagangan, pusat investasi, pusat industri, pusat pariwisata, pusat hiburan, dan sekaligus pusat segala aktivitas ekonomi lainnya. Posisi yang sangat strategis ini membuat Jakarta menjadi barometer bagi daerah-daerah lain di Indonesia. DKI Jakarta pada akhirnya berkembang menjadi kota induk yang dikitari kota satelit atau daerah suburban di sekitarnya. Sebagai kota utama yang bertindak sebagai lokomotif ekonomi dan sosial dari kota satelit atau wilayah pinggiran sekitarnya. Interaksi penduduk kota utama dan kota satelit dicirikan oleh tingkat mobilitas yang tinggi. Mobilitas ini dapat berbentuk migrasi musiman atau dapat juga berbentuk penglaju atau kommuter (bekerja di kota induk lalu kembali ke kota pinggiran).

Dalam kurun waktu 5 tahun (2006-2010) pertumbuhan ekonomi DKI Jakarta mengalami pasang surut. Meskipun terjadi pasang surut pada tahun 2010 pertumbuhan ekonomi DKI Jakarta mengalami kenaikan sebesar 6,51 persen, tahun ini merupakan tahun yang paling tinggi pertumbuhan ekonominya dibandingkan 4 tahun sebelumnya. Pada 2006 pertumbuhan ekonomi sebesar 5,95 persen sedangkan pada 2007 naik menjadi 6,44 persen dan tahun 2008 pertumbuhan ekonomi DKI Jakarta mulai mengalami penurunan sebesar 6,23 persen (turun sebesar 0,21 persen dibandingkan tahun sebelumnya). Puncaknya 
pada 2009, pertumbuhan ekonomi Jakarta mengalami penurunan yang cukup signifikan yaitu sebesar 5,02 persen (turun sebesar 1,21 persen dari tahun 2008).

Faktor utama melambatnya perekonomian Jakarta terus mengalama kenaikan adalah kinerja ekspor yang menurun. Negara-negara yang selama ini menjadi tujuan utama ekspor barang Jakarta mengalami krisis keuangan, sehingga permintaan barang Jakarta mengalami penurunan. Akibatnya sektor industri pengolahan juga mengalami penurunan produksi, yang selanjutnya mempengaruhi sektor perdagangan dan sektor pengangkutan sebagai muara semua hasil produksi. Struktur perekonomian Jakarta yang didukung oleh komponen ekspor dan impor relatif tinggi mengalami dampak yang cukup signifikan dari krisis keuangan global, namun dengan kemampuan pasar domestik yang tinggi, perekonomian Jakarta tetap mampu tumbuh positif pada tahun 2009.

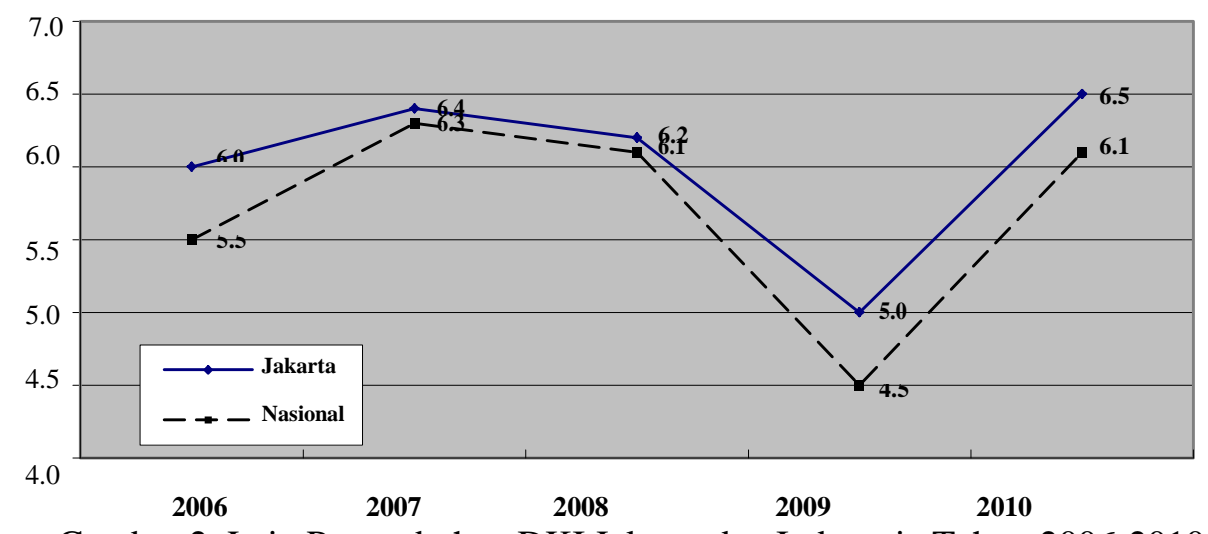

Gambar 2. Laju Pertumbuhan DKI Jakarta dan Indonesia Tahun 2006-2010

Kinerja perekonomian DKI Jakarta dalam kurun 2007-2011 menunjukkan prestasi yang cukup menggembirakan. Kondisi ini tergambar dari pertumbuhan ekonomi DKI Jakarta yang mampu tumbuh diatas 5 persen dan diatas pertumbuhan Nasional. Bahkan ketika terjadi krisis keuangan global makin dirasakan dampaknya pada semester I tahun 2009, perekonomian Jakarta hanya tumbuh sebesar 5,12 persen. Pertumbuhan ini merupakan terendah selama lima tahun terakhir, namun demikian bila dibandingkan perekonomian dunia yang tumbuh negatif, pertumbuhan ekonomi Jakarta masih terjaga.

Sementara dari sisi lapangan usaha seluruh sektor masih tumbuh positif meskipun mengalami perlambatan. Dan yang mengalami penurunan kinerja paling parah adalah sektor industri pengolahan dan sektor perdagangan, hotel, restoran. Kondisi perekonomian di Jakarta membaik selama 2010. Sebelumnya, perekonomian di kawasan Ibu Kota sempat terpengaruh oleh krisis global pada 2008 dan 2009. Namun kondisi mulai membaik pada 2010 dan pada 2011.

Secara umum dalam perekonomian secara nasional, kontribusi DKI Jakarta sebesar 16 persen dan masih menjadi penyumbang kontribusi terbesar dibandingkan provinsi lainnya. Sehingga kondisi perekonomian nasional akan sangat bergantung dengan kondisi perekonomian di Jakarta. Dilihat dari sisi 
pertumbuhan ekonomi, pertumbuhan ekonomi Jakarta hampir selalu di atas pertumbuhan nasional (lihat gambar di atas). Penyebabnya adalah struktur ekonomi DKI Jakarta ditopang oleh sektor jasa, sementara struktur ekonomi nasional masih bertumpu pada sektor pertanian dan industry pengolahan. Sektor jasa masih akan berkembang dengan cakupan yang luas (BPS Provinsi DKI Jakarta, 2012).

Sementara itu, Produk Domestik Regional Bruto (PDRB) DKI Jakarta atas dasar harga berlaku dari tahun 2007-2010 juga ikut mengalami kenaikan. Pada tahun 2007 PDRB Jakarta sebesar Rp. 566.449,36 trilyun, tahun 2008 mengalami kenaikan sebesar Rp. 677.044,74 trilyun serta tahun 2009 dan 2010 pun PDRB Jakarta terus mengalami kenaikan yaitu masing-masing sebesar Rp. 757.696,59 trilyun dan Rp. 862.158,91 trilyun. Jika ditarik rata-rata pertumbuhan PDRB DKI Jakarta dalam kurun waktu 4 tahun adalah sebesar 15 persen kenaikan dalam tiap tahunnya (Jakarta Dalam Angka 2012).

Pada dasarnya, dengan kenaikan PDRB yang dialami oleh DKI Jakarta tersebut, tentunya hal tersebut ikut membawa perkembangan yang positif terhadap pendapatan per kapita penduduknya. Pada tahun 2007 atas dasar harga berlaku pendapatan PDRB per kapita DKI Jakarta sebesar 62,49 juta rupiah, kemudian mengalami kenaikan yang cukup signifikan yaitu sebesar 19 persen pada tahun 2008 dengan nominal 74,16 juta rupiah. Sementara pada tahun 2009-2010 pendapatan per kapitanya semakin menanjak walaupun tidak signifikan yaitu 11 persen dan 19 persen dengan nominal masing-masing sebesar 82,15 juta dan 89,92 juta rupiah. Ironisnya, dengan terus naiknya angka pertumbuhan ekonomi tersebut hingga 2011, jumlah penduduk miskin di DKI Jakarta justru mengalami kenaikan hingga 0,27 persen dari 3,48 persen (tahun 2010) menjadi 3,75 persen (tahun 2011) (BPS Provinsi DKI Jakarta, 2011).

Dalam tiga tahun terakhir antara tahun 2008-2010 Anggaran Pendapatan Belanja Daerah (APBD) provinsi DKI Jakarta mengalami peningkatan dengan rata-rata kenaikan sebesar 12,7 persen pertahunnya. Adapun sumber pendapatan terbesar provinsi DKI berasal dari Pendapatan Asli Daerah (PAD) dan selebihnya berasal dari Pendapatan Transfer/Dana Perimbangan serta Pendapatan-pendapatan lain sebagainya. Dari komponen PAD, penyumbang pendapatan terbesar adalah dari sektor pajak daerah yang mencapai lebih dari 80 persen atau sebesar 47 persen dari pendapatan keseluruhan.

Realisasi pendapatan di tahun 2010 adalah sebesar 23 trilyun rupiah, angka tersebut mengalami kenaikan sebesar 20 persen dari tahun 2008 yaitu 19,2 trilyun rupiah. Perincian dana pendapatan tersebut terdiri dari PAD sebesar 12,9 trilyun rupiah, Pendapatan Transfer/Dana Perimbangan sebesar 9,5 trilyun rupiah dan Pendapatan lain-lain sebesar 515 milyar rupiah. Kenaikan pendapatan tersebut ternyata ikut diimbangi dengan pengeluaran belanja pemerintah daerah provinsi DKI Jakarta yang cukup besar yaitu sebanyak 21,5 trilyun rupiah, angka tersebut mengalami kenaikan sebesar 35 persen (15,9 trilyun rupiah) dibandingkan anggaran belanja tahun 2008 .

Total pengeluaran pemerintah provinsi yang terbesar digunakan untuk membiayai pendidikan sebesar 7,1 trilyun rupiah (33 persen), kemudian disusul 
untuk pengeluaran lain yang relatif besar yaitu pelayanan umum sebesar 4,7 trilyun rupiah (22 persen), perumahan dan fasilitas umum sebesar 3,2 trilyun rupiah (15 persen), aspek ekonomi sebesar 2,1 trilyun rupiah (10 persen), aspek kesehatan sebesar 1,9 trilyun rupiah (9 persen), aspek lingkungan hidup sebesar 1,7 trilyun rupiah ( 8 persen), aspek pariwisata dan budaya sebesar 431 milyar rupiah ( 2 persen) dan aspek perlindungan sosial sebesar 216 milyar rupiah (1 persen). Secara akumulasi dari pendapatan tersebut, di tahun 2010 pemerintah DKI masih mendapatkan surplus APBD sebesar 1,4 trilyun rupiah. Sementara tahun 2009, APBD DKI Jakarta mengalami defisit sebesar 248 milyar rupiah. Hal tersebut menandakan kondisi perekonomian di DKI mulai membaik terlihat dari kenaikan sebesar 31 persen dari pendapatan tahun lalu (Jakarta Dalam Angka 2012).

\section{Kondisi Sosial}

Sebagai Ibu Kota tentu punya daya tarik sendiri, di antaranya adalah tempat orang untuk mencari pekerjaan yang mana tujuannya untuk memperbaiki taraf kehidupan. Jakarta merupakan pusat tujuan urbanisasi bagi para penduduk dari berbagai macam daerah di Indonesia baik dari Sabang hingga Merauke. Hal tersebut dapat dilihat dari laju pertumbuhan penduduk dalam kurun waktu 10 tahun, dimana rata-rata pertumbuhannya mengalami peningkatan sebesar 1.45 persen per tahunnya. Tabel di bawah ini menunjukkan perkembangan kenaikan jumlah penduduk DKI Jakarta dari tahun 2000 sampai 2010.

Peningkatan jumlah penduduk disamping menimbulkan dampak positif tentunya juga akan menimbulkan dampak yang negatif terutama apabila pemerintahnya tidak mampu untuk mengatur laju pertumbuhan itu sendiri. Jakarta yang disebut-sebut sebagai kota Metropolitan sebenarnya banyak sekali menyimpan rasa ketakutan dan kecemasan bagi penghuninya terlebih lagi bagi para pendatang yang notabennya belum memahami karakteristik kehidupan kota ini. Tidak jarang terjadi peristiwa pencurian dalam skala kecil hingga penodongan bahkan perampokan dengan senjata tajam dalam skala besar mewarnai kota ini. Ironisnya kejadian tersebut justru dilakukan disiang bolong.

Selain itu, pengangguran, buta huruf, putus sekolah, kemiskinan hingga tuna wisma masih banyak terdapat di dalamnya. Hal tersebut masih banyak kita jumpai ketika kita jalan-jalan ke daerah pemukiman kumuh seperti yang terdapat di pinggir bantaran kali ciliwung, di bawah jembatan penyebrangan jalan hingga ke wilayah bagian paling utara Jakarta, bahkan di tengah-tengah daerah perkotaan sekalipun masih tetap ada. Sebagai penjelasan dari data tabel di bawah ini, jika dilihat menurut pendidikan tertinggi yang ditamatkan. Jumlah pengangguran terbanyak di dominasi dari kalangan masyarakat dengan tamatan pendidikan SMTA (umum dan kejuruan) dengan prosentase sebesar 40 persen dari total keseluruhan pada tahun 2011 dibulan agustus. Sedangkan jumlah pengangguran terkecil justru bukan diraih oleh masyarakat dari tamatan universitas (S1-S3) namun pada masyarakat dengan pendidikan terakhir sebagai Diploma/Akademi yaitu sebesar 3 persen dari total keseluruhan. 
Tabel 2. Pengangguran Terbuka Menurut Pendidikan Tertinggi yang Ditamatkan 2007, 2008, 2009, 2010, dan 2011

\begin{tabular}{|c|l|r|r|r|r|c|}
\hline No. & $\begin{array}{l}\text { Pendidikan Tertinggi } \\
\text { Yang Ditamatkan }\end{array}$ & $2007(\mathrm{Feb})$ & $2008(\mathrm{Feb})$ & $2009(\mathrm{Feb})$ & $2010(\mathrm{Feb})$ & 2011 (Agst) \\
\hline 1 & $\begin{array}{l}\text { Tidak/Belum Pernah Sekolah/ } \\
\text { Belum Tamat SD }\end{array}$ & 666066 & 528195 & 476302 & 606230 & 877265 \\
\hline 2 & Sekolah Dasar & 2753548 & 2216748 & 2143747 & 1522465 & 1120090 \\
\hline 3 & SLTP & 2643062 & 2166619 & 2054682 & 1657452 & 1890755 \\
\hline 4 & SMTA (Umum dan Kejuruan) & 3745035 & 3369959 & 3471213 & 3448137 & 3074946 \\
\hline 5 & Diploma I/II/III/Akademi & 330316 & 519867 & 486399 & 538186 & 244687 \\
\hline 6 & Universitas & 409890 & 626202 & 626621 & 820020 & 492343 \\
\hline & Total & 10547917 & 9427590 & 9258964 & 8592490 & 7700086 \\
\hline
\end{tabular}

Artinya dari gambaran data di atas perlu sekiranya pemerintah daerah DKI Jakarta lebih fokus untuk memperhatikan dan memperbaiki pola pendidikan serta menambah jumlah lapangan pekerjaan dengan tujuan untuk menekan laju pengangguran di tahun berikutnya. Kondisi ini tentu menjadi beban tersendiri bagi Pemerintah Provinsi DKI Jakarta, mengingat Jakarta merupakan ibukota Negara.

Berkaitan dengan Indeks Pembangunan Manusia (IPM) menurut catatan BPS Provinsi DKI Jakarta, IPM DKI Jakarta lebih tinggi dari rata-rata IPM yang dicapai nasional. Indeks Pembangunan Manusia (IPM) yang merupakan indikator komposit yang mengukur kualitas hidup manusia. IPM dibangun melalui pendekatan tiga dimensi, yaitu umur panjang dan sehat, pengetahuan, dan kehidupan yang layak.IPM menjelaskan tentang bagaimana manusia mempunyai kesempatan untuk mengakses hasil dari suatu proses pembangunan, sebagai bagian dari haknya dalam memperoleh pendapatan, kesehatan, pendidikan, dan sebagainya.

Berdasarkan Berita Resmi Statistik Provinsi DKI Jakarta No. 11/02/31/Th. XVI, 5 Februari 2014, selama tahun 2012, IPM DKI Jakarta tercatat sebesar 78,33 lebih tinggi dari rata-rata IPM yang dicapai nasional yang sebesar 73,29. Pada level provinsi, IPM DKI Jakarta adalah yang tertinggi diantara provinsi-provinsi lainnya. Pada level kabupaten/kota, IPM tertinggi dicapai oleh Kota Jakarta selatan, yaitu sebesar 80,17, dan yang terendah adalah Kabupaten Kepulauan Seribu, yaitu sebesar 71,45.Secara umum, nilai IPM DKI Jakarta selalu berada di atas angka IPM Nasional. Selama kurun waktu tahun 2002-2012, kinerja pembangunan manusia di Provinsi DKI Jakarta menunjukkan peningkatan yang cukup berarti. Hal ini ditunjukkan dengan kenaikan tren peningkatan angka IPM setiap tahunnya. Pada tahun 2002, IPM Jakarta sebesar 75,60 dan pada tahun 2012 meningkat menjadi 78,33. Kenaikan ini didukung oleh semua komponen IPM. Usia hidup penduduk Jakarta yang direfleksikan melalui angka harapan hidup, menunjukkan peningkatan dari 73,35 tahun pada tahun 2011 menjadi 73,49 tahun pada tahun 2012. Peningkatan angka harapan hidup menunjukkan adanya 
peningkatan derajat kesehatan masyarakat di Jakarta. Demikian pula yang dicapai oleh variabel lainnya. Angka melek huruf meningkat dari 99,15 persen menjadi 99,21 persen dan rata-rata lama sekolah meningkat dari 10,95 tahun menjadi 10,98 persen. Berbagai kebijakan pemerintah, baik pusat maupun daerah, seperti kebijakan pelaksanaan program wajib belajar 9 tahun, pemberian Biaya Operasonal Sekolah (BOS), dan Biaya Operasional Pendidikan (BOP) memberikan kontribusi yang cukup besar dalam pencapaian ini, disamping meningkatnya sarana dan prasarana pendidikan di Jakarta. Aspek standar hidup layak diukur dengan menggunakan nilai pengeluaran per kapita riil yang telah disesuaikan. Pada tahun 2010 nilai pengeluaran yang riil disesuaikan penduduk Jakarta adalah sebesar Rp 628,67 ribu dan pada tahun 2012 naik menjadi $\mathrm{Rp}$ 635,29 ribu.

Tinjauan terhadap kinerja pembangunan manusia kabupaten/kota administrasi di DKI Jakarta menunjukkan, Jakarta Selatan merupakan kota dengan kinerja pembangunan manusia terbaik diantara kabupaten/kota lainnya di Jakarta. Hal tersebut ditunjukkan dengan nilai IPM yang sebesar 80,17 pada tahun 2012. Berada pada peringkat selanjutnya adalah Kota Jakarta Timur dan Kota Jakarta Barat yang masing-masing sebesar 79,80 dan 79,43.

Rentang antara IPM tertinggi dan terendah pada tahun 2012 pada level kabupaten/kota mencapai 8,72 poin. Jakarta Selatan menempati peringkat tertinggi di DKI Jakarta, sedangkan IPM kabupaten Kepualuan Seribu yang menempati peringkat terendah. Angka ini sedikit melebar dibanding tahun lalu sebesar 8,66 poin. Hal ini disebabkan karena peningkatan semua komponen pembentuk IPM Kabupaten Kepulauan Seribu di tahun 2012 bergerak lebih lambat dibandingkan semua kabupaten/kota di Jakarta. Begitu juga dari lokasinya, Kabupaten Kepulauan Seribu secara geofrafis berupa kepulauan dan terpisah dengan ke lima Kota lainnya.

\section{Faktor Penyebab Konflik Gubernur dan DPRD DKI Jakarta Dalam Proses Penetapan APBD 2015}

Pemilukada juga membawa konsekuensi bila dikaitkan dengan hubungan antara Kepala Daerah dan Dewan Perwakilan Rakyat Daerah (DPRD). Pemilukada langsung cenderung melahirkan pemerintahan daerah yang terbelah (divided local government). Begitu juga dengan konflik yang terjadi antara Gubernur DKI dan DPRD DKI Jakarta dalam proses penetapan APBD tahun 2015 merupakan dampak dari adanya pemerintahan daerah yang terbelah (divided local government). Fenomena divided local government ini muncul pasca Pemilihan Gubernur DKI Jakarta tahun 2012. Pada Pemilihan Gubernur DKI Jakarta tahun 2012 putaran kedua, arah dan peta koalisi partai politik di DKI Jakarta sangat tidak berimbang. Di mana Pemilihan Gubernur dan Wakil Gubernur DKI Jakarta putaran kedua menempatkan pasangan Joko Widodo dan Basuki Tjahaya Purnama (Jokowi-Ahok) yang diusung oleh Partai Demokrasi Indonesia Perjuangan (PDIP) dan Partai Gerakan Indonesia Raya (Paratai Gerindra), dengan pasangan Fauzi Bowo dan Nachrowi Ramli (Foke - Nara) diusung oleh mayoritas partai politik yang menduduki kursi DPRD DKI Jakarta, yaitu Partai Demokrat, 
Partai Golkar, Partai Keadilan Sejahtera (PKS), Partai Persatuan Pembangunan (PPP), Partai Kebangkitan Bangsa (PKB), Partai Amanat Nasional (PAN), Partai Hanura, dan Partai Damai Sejahtera. Itu artinya pasangan Fauzi Bowo dan Nachrowi Ramli didukung oleh 81,91\% kursi partai politik di DPRD DKI Jakarta, sedangkan pasangan Joko Widodo dan Basuki Tjahaya Purnama hanya didukung oleh 18,09\%. Namun hasil Pemilihan Gubernur DKI Jakarta memenangkan pasangan Jokowi-Ahok.

Dengan kemenangan pasangan Jokowi-Ahok yang hanya didukung oleh 18,9\% kursi di DPRD berdampak pada ketidakseimbangan politik antara pemerintah daerah (kepala daerah) dan DPRD. Hal ini mengingat sistem pemerintahan daerah yang diharapkan oleh UU No. 32 Tahun 2004 tentang Pemerintahan Daerah, adanya harmonisasi hubungan kepala daerah dan DPRD, karena keduanya merupakan unsur penyelenggara pemerintahan daerah. Pemilihan Gubernur DKI Jakarta tahun 2012 telah mengantarkan kepala daerah terpilih (Jokowi) dengan suara minoritas di DPRD, kondisi semacam ini memungkinkan terjadinya instabilitas politik di daerah, bahkan dapat menghadirkan konflik yang berkepanjangan dalam menjalankan roda pemerintahan daerah. Kondisi yang demikian sebenarnya sudah diprediksi sebelumnya oleh partai koalisi pendukung Jokowi-Ahok.

Gejala munculnya divided local government di Pemerintah Daerah Provinsi DKI Jakarta pasca Pemilukada tahun 2012 adalah pada saat pembahasan RAPBD tahun anggaran 2013. Di mana pembahasan RAPBD tahun anggaran 2013 merupakan RAPBD yang pertama kali di era Jokowi sebagai Gubernur DKI Jakarta. Di mana pembahasan RAPBD tahun 2013 tertunda dari batas waktu yang telah ditentukan oleh aturan perundang-undangan. Pembahasan RAPBD yang seharusnya selesai selambat-lambatnya 31 Desember 2012, harus tertunda hingga bulan Februari 2013. Fraksi mayoritas di DPRD DKI Jakarta mengkritisi program dan kegiatan, serta anggaran yang disampaikan oleh Joko-Ahok. RAPBD tahun 2013 yang disampaikan Pemerintah Provinsi DKI dianggap tidak sesuai dengan RPJMD dan kebutuhan dasar warga Jakarta.

Fakta munculnya perpecahan antara Gubernur dan DPRD DKI memang sudah terlihat pada awal kepemimpinan Jokowi-Ahok. Gejala ini bisa terlihat pada lambatnya penyusunan dan penetapan RAPBD DKI Jakarta 2013, karena rendahnya dukungan politik Jokowi di DPRD, berimbas pada tarik-ulur penetapan RAPBD DKI 2013. DPRD DKI secara terus menerus mempertanyakan programprogram kebijakan yang terdapat dalam RAPBD yang diajukan Jokowi. Selain dukungan politik yang rendah, macetnya penyusunan dan penetapan APBD juga diperparah oleh kapasitas pemerintahan daerah yang rendah dalam mengkomunikasikan rencana pembangunan yang akan diakomodasi dalam draft APBD. Komunikasi yang dimaksud, mencakup komunikasi formal maupun informal antara eksekutif dan legislatif. Dari setiap konflik yang terjadi, aktor yang terlibat pun sama, yakni fraksi-fraksi di DPRD DKI Jakarta yang tidak mendukung Joko Widodo pada pemilihan Gubernur tahun 2012.

Dari sini dapat dikatakan bahwa fenomena-fenomena konflik dan perselisihan yang terjadi di awal kepemimpinan Jokowi sebagai Gubernur DKI 
merupakan dampak dari adanya pemerintahan daerah yang terbelah (divided local government) pasca Pemilukada. Secara teoritis, pemerintahan dengan pola pemerintahan yang bersatu (unified government) relatif lebih efektif dibandingkan dengan pemerintahan dengan pola divided government. Pada pemerintahan yang terbelah (divided government) potensi terjadinya konflik antara eksekutif dan legislatif semakin besar, terutama apabila antara DPRD dan kepala daerah tidak sejalan. Baik dalam hal anggaran, pembuatan peraturan, hingga pengawasan, potensial terjadi konflik antara DPRD dengan kepala daerah. Hal ini terjadi di pemerintahan DKI Jakarta, di mana DPRD terus menerus mempersoalkan kebijakan yang dibuat oleh Gubernur dengan berbagai hak dan fungsi yang dimiliki DPRD.

Secara garis besar, fenomena munculnya divided local government merupakan konsekuensi dari pemilihan langsung, di mana anggota DPRD dan kepala daerah dipilih secara langsung oleh pemilih. Fenomena ini kurang terlihat dalam sistem pemilihan tidak langsung, di mana kepala daerah dipilih oleh anggota DPRD. Dalam sistem pemilihan tidak langsung, kemungkinan besar kepala daerah berasal dari partai dengan kursi mayoritas di DPRD. Jika tidak ada politik uang dan suara anggota DPRD dari partai solid, calon yang didukung oleh partai mayoritas itu hampir bisa dipastikan akan terpilih sebagai kepala daerah. Fenomena divided government kerap dikaitkan dengan kecenderungan pemilih untuk memilih calon dari partai yang berbeda untuk beberapa jenis pemilihan (split-ticket voting).

Fenomena divided local government yang terjadi di DKI Jakarta menjadi penyebab utama konflik antara Gubernur dan DPRD DKI Jakarta. Terlebih lagi, jika melihat beberapa perselisihan antara Gubernur dan DPRD DKI tersebut, adanya divided local government menjadi pemicu lahirnya konflik berkepanjangan antara kepala daerah dan DPRD. Dengan kata lain, meskipun kepala daerah dapat menyelesaikan konflik dengan DPRD dalam satu kasus, namun roda pemerintahan daerah akan terus-menerus diwarnai oleh konflik berkepanjangan.

Dari sini dapat dikatakan bahwa keyakinan bahwa hubungan eksekutif dan legislatif lokal yang cenderung menganut sistem presidensialisme memberikan kekuasaan eksekutif yang lebih kuat dibandingkan sistem parlementer mulai diragukan. Presidensialisme bergantung pada keseimbangan dan pemisahan kekuasaan. Tetapi keseimbangan ini acapkali menimbulkan inmobilisasi dan kemandegan. Samuel Huntington menegaskan bahwa sebagian besar rakyat Amerika lebih menyukai dispersi kekuasaan dibandingkan konsentrasi kekuasaan. Berbeda dengan Negara berkembang, konsentrasi kekuasaan diperlukan untuk koordinasi dan pelaksanaan kebijaksanaan yang efektif. Akan tetapi kombinasi antara presidensialisme dengan sistem multipartai yang terpecah belah tampak berkecederungan menghambat kinerja sistem pemerintahan demokrasi yang stabil. Untuk mengatasi masalah yang ditimbulkan oleh kondisi pemerintahan daerah yang terbelah (divided local government), penelitian ini menemukan beberapa langkah yang bisa ditempuh, namun yang paling utama adalah komunikasi yang efektif diantara dua pihak, Gubernur dan DPRD DKI Jakarta, 
terutama dalam hal pembahasan anggaran yang merupakan hajat hidup orang banyak. Fenomena munculnya pemerintahan daerah yang terbelah (divided local government) sudah ada sejak digulirkannya pemilihan kepala daerah secara langsung oleh rakyat. Fenomena ini cenderung diakibatkan oleh sistem Pemilu legislatif daerah dan kepala daerah berbeda. Di samping itu, dalam Pemilukada faktor figur calon kepala daerah yang paling menentukan kemenangan dalam Pemilukada, bukan partai politik. Divided local government berdampak pada efektivitas pemerintahan daerah, karena pemerintahan daerah lebih diwarnai dengan pertarungan politik antara kepala daerah dan DPRD, sehingga berdampak pada kebijakan-kebijakan daerah yang bernuansa politis. Namun dampak yang paling signifikan dari fenomena divided local government adalah lahirnya konflik berkepanjangan. Untuk mengatasi hal ini kunci paling utama adalah komunikasi politik yang dilakukan oleh kepala daerah. Kepala daerah harus mampu menyamakan platform masing-masing perwakilan DPRD dengan platform-nya, sehingga dapat meredam ketegangan. Selain itu. Selain itu, kepala daerah dan DPRD juga mesti meningkatkan koordinasi, integrasi, simplifikasi, dan sinkronisasi secara efektif sehingga potensi konflik dapat diminimalisir.

Para elite partai politik juga diharapkan untuk tidak "mencampuradukkan" antara kepentingan pribadi dan kelompok dengan kepentingan publik dalam penyelenggaraan pemerintahan daerah, karena justru akan memperkeruh keadaan. Kepentingan pribadi dan kelompok yang dimaksud adalah bisa saja berupa kepentingan partai yang memposisikan diri sebagai oposisi pemerintahan. Mengingat sikap oposan yang ditunjukkan oleh mayoritas fraksi di DPRD DKI Jakarta tidak membawa perbaikan ke arah yang lebih baik. Untuk menekan perpecahan dalam pemerintahan daerah, penting juga didorong aktualiasi mekanisme check and balances dalam interaksi antara Gubernur dan DPRD DKI yang dapat diupayakan melalui tiga langkah strategis. Pertama, aktualisasi prinsip good governance seperti transparansi, akuntabilitas, dan kepastian hukum dalam manajemen pemerintahan daerah. Kedua, strategi peningkatan kinerja aksi (action performance) dan kinerja hasil (result performance), di mana kinerja aksi ditandai dengan kuantitas aktivitas dan kinerja hasil ditandai dengan kualitas produktivitas. Ketiga, strategi yang berorientasi pada peningkatan kredibilitas pemerintah daerah, kemandirian pemerintah daerah, kemitraan pada tingkat nasional dan internasional, dan peningkatan kemampuan kompetitif pemerintah daerah.

Kinerja aksi (action performance) dan kinerja hasil (result performance) dapat didorong melalui peningkatan keterampilan, profesionalitas dan kepelayanan aparatur pemerintah daerah sehingga dapat meningkatkan efisiensi dan efektifitas pengelolaan sumber-sumber daya potensial daerah kabupaten. Adapun kredibilitas pemerintah daerah juga dapat ditingkatkan apabila terjadi: (1) Pemerintah daerah dapat melaksanakan pembangunan politik lokal sesuai dengan dinamika perkembangan sosoal-ekonomi daerah; (2) Peningkatan kemampuan akomodatif pemerintah daerah terhadap tuntutan pemangku kepentingan (stakeholders); dan (3) Peningatan intensitas penanganan konflik internal dalam rangka menciptakan saling menghargai dan kerjasama optimal diantara berbagai komponen pelaku kebijakan pembangunan daerah. 
Hal yang juga tidak boleh dilupakan adalah peran pemangku kepentingan (stakeholders) khususnya Gubernur dan DPRD DKI melaksanakan dan meningkatkan koordinasi, integrasi, simplifikasi, dan sinkronisasi secara efektif, sehingga kesalahfahaman yang seringkali terjadi antara "aktor" yang terlibat dalam konflik dapat diminimalisir sehingga kebijakan dan program yang akan menjadi pedoman dasar dalam pelaksanaan pemerintahan, pembangunan, dan pembinaan kemasyarakatan. Apabila koordinasi, integrasi, simplifikasi, dan sinkronisasi betul-betul dilaksanakan dengan baik, maka tidak mustahil kondisi pemerintahan yang terbelah (divided government) sebagai hasil dari proses Pemilukada malah bisa menjadi pemicu utama akselerasi pembangunan di daerah. Pada dasarnya praktek penyelenggaraan pemerintaha daerah di era otonomi daerah menganut prinsip checks $n$ balances. Pada hakikatnya prinsip checks and balances dalam penyelenggaraan pemerintahan didasarkan pada adanya syarat tidak adanya cabang pemerintahan yang memiliki kekuasaan dominan, serta dapat dipengaruhi oleh cabang lainnya. (A government is said to have an effective system of checks and balances if no one branch of government holds total power, and can be overridden by another). Secara tersirat dapat ditangkap bahwa esensi pokok dari prinsip checks and balances adalah menjamin adanya kebebasan dari masing-masing cabang kekuasaan sekaligus menghindari terjadinya interaksi atau campur tangan dari kekuasaan yang satu terhadap kekuasaan lainnya. Dengan kata lain, inti gagasan demokrasi konstitusional adalah menciptakan keseimbangan dalam interaksi sosial politik. Namun, upaya menciptakan keseimbangan tersebut tidak dilakukan dengan melemahkan fungsi, mengurangi independensi, atau mengkooptasi kewenangan lembaga lain yang justru akan mengganggu kinerja lembaga yang bersangkutan.

Dengan demikian, checks and balances sesungguhnya bukanlah tujuan dari penyelenggaraan pemerintahan (daerah). Konsep ini lebih merupakan elemen pemerintahan demokratis untuk mewujudkan cita-cita besar membangun kelembagaan pemerintahan yang demokratis (democratic and egalitarian), bersih dan kuat (good and strong), serta mendorong perwujudan good society, melalui penyempurnaan tata hubungan kerja yang sejajar dan harmonis diantara pilar-pilar lembaga politik di daerah.

Dalam rangka mewujudkan tujuan besar tersebut, maka penerapan checks and balances dalam penyelenggaraan pemerintahan harus memperhatikan prinsip non-dichotomy (tidak berpikir dualistis atau memisahkan secara tegas fungsi pilarpilar kekuasaan); mendorong terbentuknya team-building (membangun tim); serta systemic and comprehensive (mencakup semua aspek dan seluruh pihak/stakeholders). Itu artinya di antara lembaga-lembaga politik yang ada, terdapat saling keterhubungan (interconnectedness), saling ketergantungan (interdependence), dan irisan (intercourse) yang erat satu sama lain.

Apa yang terjadi dalam penyelenggaraan pemerintahan daerah Provinsi DKI Jakarta di era Basuki Tjahaya Purnama justru tidak sejalan dengan prinsipprinsip checks and balances. Hal ini menjelaskan bahwa pada pemerintahan pronvinsi DKI Jakarta belum sepenuhnya memenuhi prasyarat atau prakondisi yang memungkinkan berkembangnya checks and balances. Pertama, belum 
optimalnya proses demokratisasi di level lembaga politik di DKI Jakarta. Artinya, kesadaran untuk secara terus-menerus melakukan perbaikan, baik dari kalangan politisi, birokrat maupun masyarakat luas belum terbangun. Kedua, tidak adanya pemahaman konsep politik kenegaraan dan kepemerintahan daerah dari segenap aktor politik pemenang kekuasaan di DKI Jakarta. Padahal dalam checks and balances dibutuhkan adanya kedewasaan politik para anggota DPRD serta kalangan birokrasi dan penegak hukum, bahkan juga kalangan masyarakat pada umumnya. Ketiga, tidak pemahaman fungsi dan peranan eksekutif dan legislatif daerah yang seimbang (asymmetric information), serta tata hubungan kerja dinamis dan produktif di antara keduanya, justru yang lahir adalah rasa kecurigaan atau kekurangpercayaan antara Gubernur dan DKI Jakarta menunjukkan adanya ketimpangan dalam pola komunikasi antar keduanya. Keempat, tidak adanya kesadaran penuh untuk memangku hak dan kewajiban masing-masing secara terbuka dan bertanggungjawab untuk mewujudkan cita-cita mewujudkan kesejahteraan daerah, khusunya untuk warga DKI Jakarta.

\section{Dampak Konflik Politik Antara Gubernur dan DPRD DKI Terhadap Penyelenggaraan Pemerintahan Daerah}

Sejarah sistem pemerintahan daerah di Indonesia telah mengalami proses yang cukup panjang sebagai gambaran sebuah dinamika dalam mengelola sebuah negara. Sampai saat ini setidaknya sudah ada tujuh undang-undang yang mengatur mengenai pemerintahan daerah, mulai dari UU No. 1 Tahun 1945, UU No. 22 Tahun 1948, UU No. 1 Tahun 1957, UU No. 5 Tahun 1974, UU No. 22 Tahun 1999, dan UU No. 32 Tahun 2004. Akan tetapi permasalahan penyelenggaraan pemerintahan daerah sepertinya tidak pernah selesai. Sampai saat ini banyak daerah otonom yang tidak mengalami kemajuan dan bahkan menjadi sangat bergantung kepada Pemerintah Pusat. Ketergantungan Pemerintah Daerah terhadap berbagai pedoman dalam menyelenggarakan urusan pemerintahan yang menjadi kewenangannya, serta pendanaan terhadap penyelenggaraan urusan itu sendiri.

Dalam kaitan ini, Osborne dan Gabler (1992) mengatakan bahwa persoalan utama yang dihadapi oleh pemerintahan dewasa ini bukan terletak pada "apa yang dikerjakan" tetapi terletak pada "bagaimana mengerjakannya".

Sehingga dalam rangka penyelenggaraan pemerintahan daerah, Kepala Daerah dan DPRD diharuskan untuk dapat menghadirkan harmonisasi hubungan serta saling bersinergi mengerjakan urusan pemerintahan yang telah menjadi kewenangannya. Hal ini yang kemudian menjadi salah satu prinsip yang mendasari UU No. 32 Tahun 2004 tentang Pemerintahan Daerah, yang menegaskan bahwa penyelenggaraan pemerintahan daerah diselenggarakan oleh pemerintah daerah dan DPRD sebagai unsur penyelenggara pemerintahan daerah, menurut asas desentralisasi, asas dekonsentrasi, dan asas tugas pembantuan.

Namun dalam praktiknya, dinamika hubungan antara kepala daerah dan DPRD menjadi salah satu diskursus paling mengemuka mengingat dampak yang ditimbulkan, secara langsung maupun tidak langsung, akan berpengaruh pada penyelenggaraan pemerintahan daerah itu sendiri. Penelitian ini sebenarnya hanya 
memfokuskan pada fenomena konflik politik antara Kepala Daerah dan DPRD, namun sesuai dengan temuan yang didapatkan dari penelitian lapangan menyebutkan bahwa terdapat dampak yang ditimbulkan dari adanya konflik antara Gubernur dan DPRD menjadi penting untuk dipaparkan. Namun meskipun demikian, dalam menjawab permasalahan apakah suatu pemerintahan yang mengalami konflik dan perpecahan mengaibatkan ketidakstabilan politikn dan berdampak pada penyelenggaraan pemerintahan, tentunya perlu dilakukan penelitian lebih lanjut dan mendalam. Karena tidak selamanya pemerintahan yang harmonis dan beriringan menhadirkan stabilitas politik, dan sebaliknya, tidak selamanya juga pemerintahan dengan kondisi konflik dan perpecahan (terjadi konflik antara kepala daerah dengan DPRD) akan mengalami ketidakstabilan politik.

Pada fenomena konflik yang terjadi antara Gubernur dan DPRD DKI Jakarta di era kepemimpinan Basuki Tjahaya Purnama, tidak menunjukkan gejala yang berdampak pada penyelenggaraan pemerintahan Provinsi DKI Jakarta. Konflik yang terjadi antara DPRD dan Gubernur DKI Jakarta hampir terjadi di setiap program-program unggulan Gubernur. Konflik yang ditunjukkan oleh DPRD juga tidak sebatas pada perbedaan pendapat yang lumrahnya terjadi di setiap daerah, namun sudah mengerucut pada penggunaan hak-hak istimewa yang dimiliki DPRD. Konflik tersebut tentu menghabiskan banyak energi dan memecah konsentrasi kedua lembaga sebagai lembaga penyelenggara pemerintahan daerah yang memiliki fungsi masing-masing.

Konflik politik antara Gubernur dan DPRD DKI Jakarta tentu mengganggu jalan pemerintahan di Provinsi DKI Jakarta. Mulai dari penundaan dalam pembahasan dan penetapan RAPBD tahun 2015. Bila dianalisa lebih jauh, Anggaran Pendapatan dan Belanja Daerah (APBD) merupakan suatu rencana keuangan tahunan pemerintah daerah yang disetujui oleh Dewan Perwakilan Rakyat Daerah (UU No. 17 Tahun 2003 pasal 1 butir 8 tentang Keuangan Negara). Semua penerimaan daerah dan pengeluaran daerah harus dicatat dan dikelola dalam APBD. Penerimaan dan pengeluaran daerah tersebut adalah dalam rangka pelaksanaan tugas-tugas desentralisasi. Sedangkan penerimaan dan pengeluaran yang berkaitan dengan pelaksanaan Dekonsentrasi atau Tugas Pembantuan tidak dicatat dalam APBD.

APBD merupakan dasar pengelolaan keuangan daerah dalam satu tahun anggaran. APBD merupakan rencana pelaksanaan semua Pendapatan Daerah dan semua Belanja Daerah dalam rangka pelaksanaan desentralisasi dalam tahun anggaran tertentu. Pemungutan semua penerimaan daerah bertujuan untuk memenuhi target yang ditetapkan dalam APBD. Demikian pula semua pengeluaran daerah dan ikatan yang membebani daerah dalam rangka pelaksanaan desentralisasi dilakukan sesuai jumlah dan sasaran yang ditetapkan dalam APBD. Karena APBD merupakan dasar pengelolaan keuangan daerah, maka APBD menjadi dasar pula bagi kegiatan pengendalian, pemeriksaan dan pengawasan keuangan daerah. Tahun anggaran APBD sama dengan tahun anggaran APBN yaitu mulai 1 Januari dan berakhir tanggal 31 Desember tahun yang bersangkutan. 
Sehingga pengelolaan, pengendalian, dan pengawasan keuangan daerah dapat dilaksanakan berdasarkan kerangka waktu tersebut.

APBD disusun dengan pendekatan kinerja yaitu suatu sistem anggaran yang mengutamakan upaya pencapaian hasil kerja atau output dari perencanaan alokasi biaya atau input yang ditetapkan. Jumlah pendapatan yang dianggarkan dalam APBD merupakan perkiraan yang terukur secara rasional yang dapat tercapai untuk setiap sumber pendapatan. Pendapatan dapat direalisasikan melebihi jumlah anggaran yang telah ditetapkan. Berkaitan dengan belanja, jumlah belanja yang dianggarkan merupakan batas tertinggi untuk setiap jenis belanja. Jadi, realisasi belanja tidak boleh melebihi jumlah anggaran belanja yang telah ditetapkan. Penganggaran pengeluaran harus didukung dengan adanya kepastian tersedianya penerimaan dalam jumlah yang cukup. Setiap pejabat dilarang melakukan tindakan yang berakibat pengeluaran atas beban APBD apabila tidak tersedia atau tidak cukup tersedia anggaran untuk membiayai pengeluaran tersebut. Dengan demikian APBD menempati posisi paling vital dalam penyelenggaraan pemerintahan daerah.

Permasalahannya, dalam sistem otonomi daerah dan desentralisasi, APBD merupakan produk kebijakan yang dibuat dan disepakati oleh Pemerintah Daerah (kelapa daerah) dan DPRD. Maka dengan tidak adanya kesepakatan antara kedua lembaga dalam penetapan APBD dampaknya keterlambatan pembiayaan program kegiatan pemerintah daerah. Bila tidak ada kata sepakat dalam penggunaan APBD, pemerintah daerah hanya dapat menggunakan biaya tidak langsung seperti belanja pegawai, listrik, air, dan sebagainya. Sementara biaya pembangunan infrastruktur, pendidikan, dan kesehatan tidak bisa digunakan hingga APBD disepakati antara Gubernur dan DPRD DKI.

Dampak dari penundaan APBD tahun 2015 oleh DPRD DKI Jakarta pada saat itu ternyata langsung berdampak pada semua program Pemerintah Provinsi DKI Jakarta tahun 2015. Program Kartu Jakarta Sehat dengan anggaran Rp 1,2 triliun, Kartu Jakarta Pintar dengan anggaran Rp. 2 trilun, anggaran Dana Bantuan Operasional Sekolah Rp. 2,51 triliun, serta anggara-anggaran lainnya. Dengan kelambatan penetapan APBD 2015, program-program prioritas Pemerintah Provinsi DKI Jakarta tertunda untuk diimplementasikan.

Konflik antara Gubernur dan DPRD DKI Jakarta juga berdampak langsung pada rencana mega proyek transportasi yakni Proyek Pembangunan MRT. Pada dasarnya Proyek Pembangunan MRT dibiayai oleh Pemerintah Pusat dan Pemerintah Provinsi DKI Jakarta serta didukung oleh Pemerintah Jepang melalui Japan International Cooperation Agency (JICA). Dukungan JICA diberikan dalam bentuk penyediaan dana pembangunan dalam bentuk pinjaman. Komitmen yang telah diberikan JICA terhadap bantuan pembangunan MRT ini adalah sebesar $¥ 125,237,000,000,-$, sedangkan loan agreement yang telah diberikan sebesar $¥ 50,019,000,000$.- terdiri dari Loan Agreement No. IP-536 sebesar $¥ 1,869,000,000$.- dan Loan Agreement No. IP-554 sebesar $¥ 48,150,000,000 .{ }^{3}$.

Pelaksanaan Pembangunan MRT melibatkan beberapa instansi, baik pada tingkatan Pemerintah Pusat, Pemerintah Provinsi DKI Jakarta, dan PT. MRT 
Jakarta. Oleh karena itu, Dokumen Anggaran yang diperlukan juga melibatkan lembaga-lembaga tersebut dengan nama program dan kegiatan berbeda namun dengan satu output yang sama, pembangunan MRT. Dana pinjaman JICA yang telah diterima Pemerintah diterushibahkan kepada Pemerintah Provinsi DKI Jakarta. Dokumen anggaran (APBN) yang berkaitan dengannya berada pada Kementerian Keuangan, Direktorat Jenderal Perimbangan Keuangan, Direktorat Pembiayaan dan Kapasitas Daerah, Sub Direktorat Hibah Daerah, nama program dan kegiatannya adalah Program Pengelolaan Hibah Negara dengan Kegiatan Penerusan Pinjaman dan/atau Hibah LN sebagai hibah kepada Pemerintah Daerah.

Pemerintah Provinsi DKI Jakarta, sebagai implementing agency, akan mencatat sebagai penerimaan dan pengeluaran dalam APBD, menempatkan dokumen pelaksanaan anggaran kegiatan pembangunan MRT pada Badan Pengelola Keuangan Daerah (BPKD) DKI Jakarta dengan nama Program dan Kegiatan Penyertaan Modal (Pembiayaan/Investasi) Pemerintah DKI Jakarta kepada PT. MRT Jakarta. Selain itu, dokumen pelaksanaan anggaran pembangunan MRT Jakarta juga ditempatkan pada BAPPEDA DKI Jakarta sebagai belanja langsung dengan nama program, Perencanaan Pembangunan Sarana dan Prasarana Kota, dengan nama kegiatan, Management Consulting Services for MRT Jakarta.

Konflik antara Gubernur dan DPRD DKI juga berdampak pada penyerapan anggaran pada APBD DKI Jakarta tahun 2014 semakin rendah. Dengan adanya konflik tersebut efektivitas penyelenggaraan pemerintahan provinsi DKI Jakarta tahun 2014 sehingga penyerapan anggaran semakin rendah dibandingkan dengan tahun sebelumnya yang hanya mencapai 80 persen. Kondisi ini tentu menjadi permasalahan yang serius, konflik yang bersumber dari perbedaan kepentingan politik berdampak pada seluruh penyelenggaraan pemerintahan daerah, khususnya berkaitan dengan menurunnya penyerapan APBD 2014 yang akan berdampak langsung maupun tidak langsung pagi proses pembangunan di DKI Jakarta.

Dalam kaitannya dengan efektivitas penyelenggaraan pemerintahan daerah, implementasi kebijakan publik justru merupakan batu sandungan terberat dan serius bagi efektivitas pelaksanaan kebijakan pembangunan di bidang sosial dan ekonomi. Salah satu hambatannya adalah kekuatan-kekuatan politik dan birokrasi pemerintahan daerah belum merupakan kesatuan yang efektif, efisien, dan berorientasi kepada tujuan. Oleh karena itu, untuk memperoleh pemahaman tentang implementasi kebijakan publik, seharusnya tidak hanya menyoroti perilaku dari lembaga administrasi publik yang bertanggung jawab atas sesuatu program dan pelaksanaannya, namun juga perlu mencermati berbagai jaringan kekuatan politik, ekonomi, dan sosial yang langsung atau tidak langsung berpengaruh terhadap perilaku yang terlibat dalam suatu program dari keluarnya suatu kebijakan publik.

Jika hal ini dikaitkan dengan sebuah kebijakan publik yang dikeluarkan melalui program Kartu Jakarta Sehat dengan menggunakan kerangka Institutional Analisys Development (IAD) yang terdapat dalam bukunya Margaret M. Polski dan Elinor Ostrom, "An Institutional Framework for Policy Analysis and Design", 
maka aktor-aktor yang bisa diidentifikasi dalam program tersebut adalah: (i) Jokowi-Ahok; (ii) Dinas Kesehatan; (iii) Dinas Kependudukan dan Catatan Sipil; (iv) Dinas Kesehatan; (v) Puskesmas; (vi) Rumah Sakit Rujukan; (vii) DPRD; dan (viii) Masyarakat miskin. Kesemua elemen tersebut mesti memiliki persepsi yang sama sebagai sebuah entitas yang utuh sehingga implementasi program yang direncanakan dapat berjalan sesuai dengan mestinya.

Dalam kasus konflik Gubernur dan DPRD DKI Jakarta, DPRD memang menjadi kuat, tetapi kekuasaan yang dimiliki tidak dipakai untuk menciptakan prinsip check and balance. Justru sebaliknya DPRD kemudian memanfaatkan kekuasaan untuk kepentingan menjatuhkan Gubernur dan Wakil Gubernur DKI Jakarta. Sementara itu, Gubernur juga memiliki posisi yang kuat karena mampu mempertahankan kekuasaan dari tekan politik DPRD, tapi kekuatan Gubernur menjadi kurang efektif karena tidak memiliki dukungan politik DPRD. Melihat fakta akibat konflik tersebut, ruang konflik seperti tidak bisa lokalisir, sehingga berdampak pada proses penyelenggaraan pemerintahan daerah. Pada hal jika dicermati, akar konflik berawal dari proses pemilihan gubernur yang melahirkan banyak kekecewaan partai politik sampai terjadi hilangnya kepercayaan DPRD terhadap Gubernur Basuki Tjahaya Purnama dan kemudian merembet pada aktivitas pemerintahan.

Jadi, subtansi konflik bersumber pada persoalan politik, namun dampaknya kedua belah pihak memanfaatkan aktivitas pemerintahan sebagai alat unjuk kekuasaan. DPRD dengan otoritasnya mencari kelemahan dari setiap kebijakan Gubernur. Dalam konteks fenomena tersebut, terjadi pencampuradukan antara persoalan politik dan urusan administrasi pemerintahan. Penyelenggaraan program Kartu Jakarta Sehat, pembahasan RAPBD dan program-program Pemerintah Provinsi DKI lainnya merupakan urusan administrasi pemerintahan yang harus berjalan sebagaimana mestinya, tanpa harus terpengaruh persoalan konflik. Sementara dendam dan kekecewaan politik merupakan urusan politik karena terkait masalah dukungan dan legitimasi politik.

Antara aktivitas politik dengan aktivitas pemerintahan dalam praktek pemerintahan bisa ditelaah dalam dua bentuk. Pertama, dalam internal pemerintah daerah. Di lingkungan pemerintah daerah, dikenal ada yang namanya pejabat politik, yaitu gubernur dan wakil gubernur yang dipilih rakyat, dan pejabat birokrasi yaitu jabatan karier di birokrasi pemerintahan, seperti sekretaris daerah, kepala dinas, dan seterusnya. Jadi, walaupun birokrasi ditempatkan dalam kedudukan yang netral, dalam prakteknya muncul birokrasi partisan karena mereka sangat loyal dan berafiliasi politik kepada parpol yang menduduki jabatan politik, padahal secara formal PNS tidak menjadi salah satu anggota partai politik. Berkembangnya birokrasi partisan, berakibat birokrasi tidak mandiri dan tidak memiliki kekuatan penyeimbang kekuasaan dengan kedudukan pejabat politik. Kedua, aktivitas politik, secara kelembagaan lebih banyak diperankan DPRD karena lembaga ini adalah pencerminan kedaulatan rakyat. Pemahaman politik dalam konteks aktivitas politik di DPRD harus dipahami dalam politik kebijakan, yaitu sebatas melakukan fungsi formulasi kebijakan dan kontrol terhadap implementasi kebijakan. UU No. 32 Tahun 2004 Pasal 19 menyebutkan 
penyelenggara pemerintahan daerah adalah pemerintah dan DPRD. Pasal ini, secara jelas memosisikan kedudukan DPRD sebagai penyelenggara pemerintahan. Implikasi pasal ini, aktivitas penyelenggaraan pemerintahan harus dilakukan bersama-sama antara DPRD dan kepala daerah. Aktivitas penyelenggaraan ini meliputi tugas-tugas desentralisasi dan tugas pembantuan. Ketentuan pasal ini menekankan baik kepala daerah maupun DPRD dalam aktivitas penyelenggaraan pemerintahan menekankan pada service sphere bukan pada political sphere. Pemahaman politik dalam perspektif UU No. 32 Tahun 2004 tidak menjangkau pada penjatuhan kepala daerah karena dalam UU ini tidak dikenal dengan sistem parlementer.

Dalam UU Nomor 32 Tahun 2004 sama sekali tidak dikenal pemakzulan (impeachment) terhadap kepala daerah melalui mosi tidak percaya. Sebab, tidak ada aturan yang memungkinkan masyarakat dapat secara langsung mengjatuhkan kepala daerah. Namun, DPRD bisa mengusulkan pemberhentian kepala daerah dan wakil kepala daerah kepada Presiden jika memenuhi ketentuan Pasal 29 atau diberhentikan sementara oleh Presiden apabila melakukan tindak pidana kejahatan (Pasal 30-32). Kajian tersebut menunjukkan dalam penyelenggaraan pemerintahan daerah, sebenarnya ada pemisahan yang tegas antara sifat wewenang kepala daerah sebagai pejabat politik dan fungsi birokrasi. Artinya, spirit UU No. 32/2004 menekankan pada terwujudnya tertib pemerintahan sehingga fungsi pelayanan pada masyarakat tidak terganggu. Oleh sebab itu, kendati terjadi konflik antara DPRD dan Gubernur, proses penyelenggaraan pemerintahan harus terjaga dan bisa berfungsi sebagaimana mestinya.

\section{SIMPULAN}

Diskursus tentang pola relasi kekuasaan antara kepala daerah dan Dewan Perwakilan Rakyat Daerah (DPRD) menjadi kajian menarik dalam sistem otonomi daerah dan desentralisasi. Alasan yang mendasari mengingat dalam penyelenggaraan pemerintahan daerah hubungan antara kepala daerah dan DPRD mengalami pasang surut, padahal semangat yang dibangan dalam UU No. 32 Tahun 2004 tentang Pemerintahan Daerah, dan UU No. 9 Tahun 2015 tentang Perubahan Kedua Atas UU No. 32 Tahun 2004 tentang Pemerintahan Daerah, menghendaki adanya relasi pemerintahan daerah yang harmonis dan bersinergi dami terwujudnya pemerintahan yang baik dan efektif dalam mewujudkan kesejahtaeraan masyarakat lokal. Sistem otonomi daerah, kepala daerah dan DPRD menjadi unsur penyelenggara pemerintahan daerah, yang berarti kedunya berkedudukan sejajar, sebagai mitra kerja. Namun dalam prakteknya, pasang surut hubungan kepala daerah dan DPRD dipengaruhi oleh dinamika politik yang berkembang di daerah, seperti halnya yang terjadi dalam Konflik Gubernur dan DPRD DKI Jakarta Dalam Proses Penetapan APBD 2015.

Dari hasil penelitian disimpulkan bahwa adanya fakta pemerintahan daerah yang terbelah (divided local government) di Pemerintahan Provinsi DKI Jakarta. Munculnya fenomena divided local government di DKI Jakarta merupakan imbas dari sistem Pemilukada yang dapat menghadirkan kekuatan politik baru di pemerintahan daerah yang berbeda dengan hasil Pemilihan Umum 
legislatif daerah. Hasil penelitian menyebutkan bahwa fenomena divided local government yang terjadi di DKI Jakarta menjadi penyebab utama munculnya konflik antara Gubernur dan DPRD DKI Jakarta. Divided local government menjadi pemicu lahirnya konflik berkepanjangan antara kepala daerah dan DPRD. Dengan kata lain, meskipun kepala daerah dapat menyelesaikan konflik dengan DPRD dalam satu kasus, namun roda pemerintahan daerah akan terus menerus diwarnai oleh konflik berkepanjangan.

Fenomena divided local government di DKI Jakarta merupakan dampak negatif dari sistem pemilihan umum kepala daerah yang dapat merubah peta politik lokal. Hal ini juga dimungkinkan terjadi di daerah-daerah otonom lainnya di Indonesia, mengingat sistem Pemilukada dan pola koalisi partai politik di daerah cenderung menghasilkan kekuatan politik baru di daerah. Faktor utama penyebab munculnya pemerintahan daerah yang terbelah adalah terkait dengan perbedaan sistem pemilihan umum DPRD dan sistem Pemilukada berbeda. Pada sistem pemilihan umum yang digunakan untuk memilih anggota DPRD adalah sistem pemilihan umum proporsional dengan besaran daerah pemilihan 3 hingga 10 kursi dan penetapan calon terpilih dilakukan berdasarkan urutan jumlah perolehan suara di antara calon tanpa harus mencapai bilangan pembagi pemilih (BPP).

Ada tiga konsekuensi sistem pemilihan umum seperti ini. Konsekuensi tersebut adalah (1) calon anggota DPRD lebih aktif melakukan kampanye dengan segala cara yang mungkin daripada partai politik (parpol cenderung lebih sebagai event organizer daripada sebagai peserta Pemilu) karena jumlah suara yang diperlukan untuk terpilih tidak terlalu besar. Karena itu, pemilihan umum anggota DPRD cenderung lebih menjadi arena persaingan antarcalon dari partai yang sama di dapil yang sama daripada persaingan antarpartai. (2) Pemilih lebih cenderung memberikan suara kepada seorang calon (yang berarti memberikan suara kepada partai politik yang mencalonkannya) daripada kepada partai karena setiap calon telah melakukan pendekatan dari rumah ke rumah dengan segala cara yang mungkin. (3) Karena jumlah calon dari setiap partai sebanyak kursi yang diperebutkan di setiap dapil dan setiap calon telah berupaya keras mendapatkan suara dengan segala cara yang mungkin, dua hal akan terjadi sebagai akibatnya.

Konflik antara Gubernur dan DPRD DKI Jakarta akhirnya menemukan titik temu setelah melalui proses panjang dalam upaya penyelesaiannya. Pola penyelesaian konflik tersebut dilakukan dengan pola mediasi dengan melibatkan Kementerian Dalam Negeri Republik Indonesia. Pendekatan semacam ini dalam termininologi ilmu politik termasuk dalam penyelesaian konflik dengan pendekatan mediasi. Di mana dalam penyelesaian konflik Gubernur dan DPRD menggunakan pihak ketiga dalam penyelesaiannya, untuk menemukan titik temu yang saling menguntungkan kedua belah pihak, yang berkaitan dengan penetapan APBD. Agenda dilakukannya kompromi politik, sebenarnya merupakan sesuatu yang lazim dan wajar, bila konflik antar lembaga politik di DKI telah menciptakan instabilitas politik dan kemelut yang berkepanjangan. Kompromi politik yang tengah dibicarakan didasarkan pada beberapa alasan, yaitu: pertama, pemegang kekuasaan eksekutif bukan berasal dari kekuatan politik yang 
mayoritas, namun merupakan hasil dari kompromi politik. Kedua, terjadi kebuntuan di dalam proses pengambilan keputusan untuk menentukan legitimasi pemegang kewenangan.

Kompromi politik mampu meredakan konflik dan pertikaian politik yang mengganggu jalannya pemerintahan daerah. Hal ini menjelaskan bahwa ketidakmampuan kekuasaan suatu sistem politik menterjemahkan tuntutantuntutan ke dalam kebijakan akan berkonsekuensi kepada dilakukannya kompromi politik. Dari sini dapat dikatakan bahwa makna dari kompromi politik merupakan upaya untuk mencapai solusi atas berbagai persoalan politik secara substansial dengan melibatkan berbagai kekuatan politik. Pada hakekatnya, kompromi politik dilakukan sebagai pengakuan bahwa kekuasaan yang ada tidak kokoh atau lemah. Dapat juga diartikan sebagai upaya antisipasi dari kekhawatiran terjadinya konflik yang berkepanjangan.

\section{DAFTAR PUSTAKA}

Abdul Wahab, Solichin. (1990). Pengantar Analisis Kebijaksanaan Negara, Rineka Cipta, Jakarta

Ali, Riaz. (2006). Bangladesh in 2005 Standing at a Crossroads. Asian Survey 2006, 46 (1): 107-113.

Amal, Ichlasul. (2000). (ed). Teori-Teori Mutakhir Partai Politik, Cetakan ketiga. Yogyakarta: PT.Tiara Wacana Yogya.

Amal, Ichlasul. (1996).Teori-Teori Mutakhir Partai Politik, Cetakan kedua. Yogyakarta: PT.Tiara Wacana Yogya, 1996.

Asshiddiqie, Jimly. (2000). Kapita Selekta Teori Hukum; Kumpulan Tulisan Tersebar Jimly Asshiddiqie. Jakarta: FH UI.

Bottomore, TB. (2006). Elite dan Masyarakat, diterjemahkan oleh Abdul Haris. Jakarta: Akbar Tandjung Institute.

Bottomore, Tom et al. (1979). Karl Marx: Selected Writings in Sociology and Social Philosphy. Victoria: Penguin Books.

Budiardjo, Miriam. (1991). Aneka Pemikiran Tentang Kuasa dan Wibawa. Jakarta: Pustaka Sinar harapan.

Budiardjo, Miriam. (2000). Dasar-Dasar Ilmu Politik. Jakarta: Gramedia Pustaka Utama. 
Budiardjo, Miriam (2008). Dasar-Dasar Ilmu Politik Edisi Revisi. Jakarta: Gramedia Pustaka Utama.

Buzan, Barry. (1998). Security: a New Framework for Analysis. United States of America: Lynne Rienner Publisher, Inc.

Creswell, W.J. (2010). Reseach Design Qualitative and Quantitative Approach. Penerjemah Achmad Fawaid. Yogyakarta: Pustaka Pelajar.

Collier, Paul M. (2003). Natural Resources, Development and Conflict: Channels of causation and Policy Interventions. World Bank.

Dahrendorf, Ralf. (1986). Konflik dan Konflik dalam Masyarakat Industri. Terjemahan Ali Mandan. Jakarta: Rajawali.

Dwipayana, Ari. (2005). Teori Politik. Yogyakarta: PLOD-UGM.

Eriyanto. (2007). Pilkada dan Pemerintahan Yang Terbelah (Divided Government). Lingkaran Survei Indonesia, Edisi 07.

Fisher, Simon dan SN. Kartikasari. (2001). Mengelola Konflik: Ketrampilan dan Strategi Untuk Bertindak. Jakarta: The British Council.

Haryanto. (1990). Elit, Massa dan Konflik. Yogyakarta: Pusat Antar Universitas-Studi sosial UGM.

Haryanto. (2005). Kekuasaan Elite: Suatu Bahasan Pengantar, Yogyakarta: PLOD UGM.

Hermawan, Yulius P. (2007). Transformas(i dalam Studi Hubungan Internasional: Aktor, Isu dan Metodologi. Yogyakarta: Graha Ilmu.

Islamy, Irfan. (1997). Prinsip-prinsip Perumusan Kebijaksanaan Negara. Bina Aksara: Jakarta.

Kantaprawira, Rusadi. (2004). Sistem Politik Indonesia: Suatu Model Pengantar. Bandung: Sinar Baru Al Gesindo.

LaPorte, T., \& Keller, A. (1996). Assuring Institutional Constancy: Requisite for Managing Long-Lived Hazards. Public Administration Review, 56(6), 535544. doi: $10.2307 / 977252$

Keller, Suzanne. (1995). Penguasa dan Kelompok Elite : Peranan Elite-Penentu dalam Masyarakat Modern. Jakarta: PT RajaGrafindo Persada. 
Lasswell, Harold D. (1950). A Study of Power. New York: Free Press.

Magnus, Oberg and Strom Kaare (ed.). (2008). Resources, Governance and Civil Conflict. London: Routledge and New York: Taylor \& Francis Group.

Mas'oed, Mochtar dan Colin Mac Andrews. (2006). Perbandingan Sistem Politik. Yogyakarta: Gajah Mada University Press.

Mashad, Dhurorudin. (2005). Konflik Elite Politik Di Pedesaan. Yogyakarta: Pustaka Pelajar \& Lembaga Ilmu Pengetahuan Indonesia.

Miles, M.B \& Huberman A.M. 1984, Analisis Data Kualitatif. Terjemahan oleh Tjetjep Rohendi Rohidi. 1992. Jakarta : Penerbit Universitas Indonesia

Marbun, B.N. (1985). Manajemen dan Kewirausahaan Jepang. Jakarta: PT Gramedia.

Marbun, B.N. (2005). DPRD dan Otonomi Daerah. Jakarta: Sinar Harapan. Online Access: http://opac.dpr.go.id/catalog/index.php?p=show_detail\&id=21428

Michels, Robert. (1984). Partai politik: Kecenderungan Oligarkis dalam Birokrasi. Jakarta: CV Rajawali.

Migdal, Joel. (2001). State in Society: Studying How States and Societies Transform and Constitute One Another. Cambridge University Press.

Moleong, Lexy J. 2007. Metodologi Penelitian Kualitatif. Edisi Revisi. Bandung: PT Remaja Rosdakarya

Mulyana, Deddy.2002 Metodologi Penelitian Kualitatif. Bandung : PT Remaja Rosdakarya

Nurcholis, Hanif. (2005). Teori dan Praktik Pemerintahan dan Otonomi Daerah. Jakarta: Gransindo.

Parsons, Talcott. (1957). The Distribution of Power in American Society. World Politics.

Prihatmoko, Joko J. (2008). Mendemokratiskan Pemilu: Dari Sistem Sampai Elemen Teknis. Yogyakarta: Pustaka Pelajar.

Rauf, Maswadi. (2001). Konsensus dan Konflik Politik: Sebuah Penjajakan Teoritis. Jakarta: UI Press. 
Ross, Marc Howard. (1993). The Management of Conflict: Interpretations and Interests in Comparative Perspective. Yale University Press.

Sanit, Arbi. (1985). Perwakilan Politik Di Indonesia. Jakarta: CV. Rajawali, 1985.

Sarundajang, S.H. (2004). Babak Baru Sistem Pemerintahan Daerah. Jakarta: Kata Hasta Pustaka.

Surbakti, Ramlan. (1999). Memahami Ilmu Politik. Jakarta: Grasindo.

Sidel, J. (1999). Capital, Coercion, And Crime: Bossism in Philippines. Stanford University Press.

Soekanto, Soerjono. (2002). Sosiologi Suatu Pengantar. Jakarta: PT Raja Grafindo Persada.

Sugiyono. 2010. Metode Penelitian Pendidikan Pendekatan Kuantitatif, kualitatif, dan $R \& D$. Bandung: Alfabeta

Surbakti, Ramlan. (1992). Memahami Ilmu Politik. Jakarta: Gramedia Widiasarana.

Targonski, Rosalei ed. (2002). Garis Besar Pemerintahan Amerika Serikat, diterj. Sumantri AR. Dkk, Kantor Program Informasi Internasional Departemen Luar Negeri Amerika Serikat.

Osborne, David dan Ted Gaebler. (1992). Reinventing Government: How the Entrepreneurial Spirit is Transforming the Public Sector, diterjemahkan oleh Abdul Rosyid.1996. Mewirausahakan Birokrasi: Mentransformasikan Semangat Wirausaha ke dalam Sektor Publik. Jakarta: Pustaka Binaman Pressido.

Varma, SP. (1990). Teori Politik Modern. Jakarta: PT. Raja Grafindo Persada, 2001. Wahab, Solichin Abdul. Pengantar Analisis Kebijakan Negara. Jakarta: Rienika Cipta.

Varma, SP. (2001). Teori Politik Modern. Jakarta: PT. Raja Grafindo Persada.

Weber, Max. (1946). Essay in Sociology, diterjemahkan oleh H.H. Gerth dan C. Wright. New York: Oxford University Press.

Weber, Max. (1947). The Theory of Social and Economic Organization. diterjemahkan oleh A.M. Henderson dan Talcott Parsons, disunting dan diberi pendahuluan oleh Talcott Parsons, The Free Press of Glencoe. 